\title{
South Asia-Perennial Backwater or Object of Biased Assessment: A Discussion Based on Current Archaeological, Anthropological, and Genetic Evidence
}

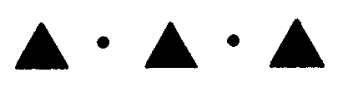

\author{
VARUN SINGH
}

\section{INTRODUCTION}

The DEVELOPMENT OF A BIPEDAL GAIT WITH PROGRESSIVE INCREASE in brain size has been well recorded in Africa. The appearance of this early human form in the rest of the world has been attributed to a particularly volatile period in earth's history. According to Larick (2004:32), Homo erectus and mammals took advantage of the instability during this brief period called the "Olduvai subchron" (1.98-1.79 mya [million years ago]) and crossed the Tethys corridor connecting the East African Rift with Southeast Asia. China and Java in Southeast Asia boast a rich fossil collection of this early human ancestor. Europe had shown no evidence of the presence of $H$. erectus until recently when a specimen was recovered in Dmanisi, Georgia. The subject of human evolution in Africa and the role played by ancient hominids of the European fossil record has been much debated and is considered beyond the scope for this discussion. Some aspects of human evolution, on the other hand, in relation to the South Asian skeletal record and in reference to the East and South-East Asian evidence are considered important and are discussed in relevant sections.

The mitochondrial or maternal DNA (mtDNA) evidence, along with archaeological evidence for a coastal spread of modern man, has prompted a revision of the long-held view that suggested Europe as the place where modern man first arrived from Africa. The remainder of the world, it was believed, was then populated by the descendants of these Cro-Magnons. James and Petraglia (2005), the first western authors to include South Asia in a discussion on "human evolution and symbolic behavior" have followed in the footsteps of Klein, who in 2000 had singled out the European achievement of some 40-50 kyr ago as exclusive. Comparing the scanty South Asian, especially Indian, evidence from the same period with the European voluminous data set, James and Petraglia have judged 
South Asians as inferior, as having failed to match the revolutionary package accomplished by the Europeans. They have succeeded in painting a very confused picture of the arrival and evolution of hominids in South Asia, an area already brilliantly covered by Kenneth Kennedy in his masterly God-Apes and Fossil Men published in 2000. Kennedy's monumental work on South Asia, spanning some four decades, places him in a position of primacy. His seminal work also forms the main source of reference on Palaeo- and Prehistoric anthropology of South Asia.

Viewpoints and proposals put forward by anthropologists concerning the evolution of human behavior are by their own admission opinions based on what Lahr and Foley (1998:143) have aptly called "empirical evidence." Klein himself is circumspect, calling his ideas "hypothetical" and the archeological evidence "noisy" (2000:33). Klein tentatively proposed that what the Europeans had achieved was the result of an abrupt and radical shift in human evolution, the likes of which was not seen elsewhere in the world. This view has been described as an example of a "Eurocentric bias" by Lahr and Foley, as well as McBrearty and Brooks (Stringer 2002:575). These anthropologists have pointed out that similar changes were developing in Africa well ahead of what happened in Europe.

The dogmatic and negative judgment served by James and Petraglia, that "it is possible that the members of our species that first colonized South Asia were not behaviorally modern - that they were incapable of fully symbolic thought," can also be called biased on two counts (James and Petraglia 2005:S15). First, the sheer scale of research and effort expended in Europe and Africa cannot be used as a measure for comparison, for the simple reason that neither South Asia nor East-Southeast Asia can hope to succeed in such an assessment. There are no paleontologists in South Asia, not to speak of specialists like archaeobotanists and archaeozoologists, who have worked on this issue. Whatever evidence has accumulated in South Asia has been the work of a handful of dedicated archaeologists who in the last three or four decades have managed to collect enough data to be noteworthy. But South Asia still falls considerably behind when it comes to total number of sites excavated and subjected to the kind of detailed analysis possible in the west. Dating techniques also remain a major issue as many modern techniques have become available only in recent years. For instance the division of the European Upper Palaeolithic into 13 regions with many sites in each and AMS dating for each (Djindjian et al. 2003) has to be compared with only 4 sites in India (Raju and Venkatasubbaiah 2002:103). As will be shown later, these meager sites were not subjected to the kind of analysis that deserves their being considered for comparison. As for the AMS dates, they can also be counted on the fingers of one hand.

Second, there is a total lack of understanding and appreciation that cultures in other parts of the world may have stamped their own signature during evolution. The absolutism exercised by James and Petraglia in their assessment betrays an ignorance of many fundamental aspects of the South Asian cultures, a subject we will return to later. Klein's "unique revolutionary package" of Europe, which he thought resulted from an abrupt change caused by mutation, also exposes a considerable lack of grasp of the basic principles of genetics. As evolution of human behavior is not the focus of this discussion, Chris Stringer's balanced and authoritative review (2002) has been chosen as a point of reference for discussions on human evolution in relation to the South Asia. 
This discussion traces the evidence both archaeological and anthropological from the time of the presence of modern man's ancestor to the evolution of Neolithic and Chalcolithic cultures that culminated in the great Indus Civilization of the third millennium B.C. First forays into the study of South Asia's ancient past were carried out by British enthusiasts, both amateur and professional. Since India's independence from the British, the volume of information has grown but in a haphazard and erratic manner. While a lot of attention has been focused on discovering the ancestors and successors of the Indus Civilization, hardly any work has been done to determine the evolution of faunal and floral species during Earth's evolution prior to the Holocene. There are no biological anthropologists being trained in India now, as the universities no longer list courses in this field. Those few who are still practicing assiduously follow the long abandoned practice of racial typing that formed part of their training. Importantly, the evidence that is presented has to address whether South Asia was populated from outside, as South Asia has always been regarded as a perennial backwater-especially since its colonial British days. In reviewing the evidence, the article has been divided into four sections dealing with (1) the lithic (stone tool) evidence, (2) the biological anthropological evidence, (3) the genetic evidence, and (4) the cultural evidence.

\section{STONE TOOLS: EVIDENCE OF EARLY HUMANS IN SOUTH ASIA}

Stone artifacts thought to reflect evolving new skills have long been considered evidence for the presence of both "pre-modern," as well as modern humans even in the absence of hominid skeletal remains. The division of South Asian stone tool evidence into Lower, Middle, and Upper Palaeolithic Eras, as dictated by the western approach, immediately runs into difficulty as the evidence does not follow the same ordered chronology seen in the west. Lower Palaeolithic (Acheulian) stone artifacts have been found in many locations, the most famous being the Soan (Sohan tradition) of the northwest. The main difficulty in this lithics-based chronological stratification relates to the emergence of the Mesolithic tradition in South Asia at about the same time as the European Upper Palaeolithic.

However, the most significant barrier to research advancement is in the dating of archaeological sites, which remains problematic, one factor being the general absence of datable organic matter from the sites (Biagi 2004:210). In addition, the very early tools found by Dennel and associates at South Asian sites have not met with wide acceptance. The earliest dates for these flakes found on the surface in the northwest of the region (Pakistan) are 2.2-1.9 mya (Rendell et al. 1989). Dennel and colleagues in 1993 published finds of further early stone tools from Pabbi Hills in Punjab (Pakistan) that were dated to 1.8-1.6 mya (Dennel et al 1993:60). Both of these finds have not been accepted, although Kennedy and others feel that if the largely typologically based dates were confirmed, these artifacts would identify the presence of the earliest human tool maker in South Asia, at par with Africa (Kennedy 2000:132). Indian tool assemblages cover all major epochs of tool making from Acheulian of the Lower Paleolithic to Middle Paleolithic and also Upper Paleolithic. V. N. Misra (2001:495) and Dennel (in response to James and Petraglia 2005:S17) both felt that with better dating 
Table i. Most of the Dates So far COME From Central and WeStern INDian provinces of Madhya Pradesh, Rajasthan, Maharashtra. Southern Indian dates are mainly for Acheulian and Upper paleolithic cultures. Upper Paleolithic dates from Belan Valley in North India have not been InCluded.

(FrOM MisRa 2OOI AND 2002).

\begin{tabular}{|c|c|c|c|}
\hline DATES-KYR & DATING METHOD & LOCATION & REgion \\
\hline \multicolumn{4}{|c|}{ ACHEULIAN-LOWER PALEOLITHIC } \\
\hline $700-400$ в.Р. & $\begin{array}{l}\text { Magnetic Polarity } \\
\text { Stratigraphy }\end{array}$ & Sindh and Punjab & Pakistan \\
\hline $1400-7.5$ в.Р. & Potassium/Argon & Bori, Maharashtra & West India \\
\hline 390-150 в.Р. & Thorium $^{230}$, Uranium $^{234}$ & $\begin{array}{l}\text { Umrethi, Didwana } \\
\text { Saurashtra, Rajasthan }\end{array}$ & West India \\
\hline 350-166 в.Р. & Thorium $^{230}$, Uranium $^{234}$ & Hungsi-Baichbal Valley & South India \\
\hline $\begin{array}{l}150-100 \text { в.Р. } \\
40-10 \text { в.Р. }\end{array}$ & $\begin{array}{l}\text { MIDDI } \\
\text { Thorium }^{230} \text {, Uranium } \\
\text { Radiocarbon }(>20 \text { dates)- } \\
\text { from shell and bone }\end{array}$ & $\begin{array}{l}\text { PALEOLITHIC } \\
\text { Didwana, Rajastham } \\
\text { Northern Deccan and } \\
\text { Central India }\end{array}$ & $\begin{array}{l}\text { West India } \\
\text { South and Central India }\end{array}$ \\
\hline 30-10 в.Р. & UPPE & $\begin{array}{l}\text { PALEOLITHIC } \\
\text { Madhya Pradesh, } \\
\text { Rajasthan, Maharashtra }\end{array}$ & Central and West India \\
\hline 12-2 в.р. & Radiocarbon & $\begin{array}{l}\text { SOLITHIC } \\
\text { Madhya Pradesh and } \\
\text { western India }\end{array}$ & Central and West India \\
\hline
\end{tabular}

techniques the Acheulian horizon in India would be pushed back to about 700 kyr B.P.

Only a brief outline of the South Asian lithic tradition can be accommodated here. Dates and sites where datable stone tools belonging to the three Palaeolithic periods have been found are set out in Table 1. Bhimbetka, a collection of rockshelters and caves in central India affords the best example of the three lithic traditions. Despite the discovery of Acheulian, Middle Palaeolithic, Upper Palaeolithic, and Mesolithic stone tools within one cave complex designated as III-F-23, barely a stone's throw away from rockshelters with paintings, this site revealed no datable material (Misra 1985:35-47). Wakankar, the discoverer of this rockshelter and cave complex felt that the mural paintings in all probability had a longer evolution and time framework than the Mesolithic period he was persuaded to accept for their date (Wakankar and Brooks 1976:102).

In a review of the evidence for Middle Palaeolithic stone assemblages, Pal (2002:67-84) has stressed that an enormous amount of information relating to the sites containing flaked artifacts still needed collecting, including ethnoarchaeological data on modes of production, an understanding of the differences in raw materials used and their regional patterns. Studies such as microwear analysis could elucidate edge-wear patterns relevant to tool use and function, and many modern methods of lithic analysis employed in other regions of the world could be used. It seems that a fuller picture of the lifeways of the Middle Palaeolithic tool user and thus culture cannot be adduced from the present South Asian evidence. 
Raju and Venkatasubbaiah, in assessing the evidence for Upper Paleolithic stone tools (2002:85-103), have stated that only four sites have been well studied, but even then only techno-typology and surface scatter patterns were examined. They propose that excavation of primary sites on a large scale in order to recover human skeletal remains, associated faunal remains and other biological evidence, along with lithic material is essential to building a picture reflecting the Upper Palaeolithic man's lifeways and culture. A few discoveries that hint at the lifeways and cultures from this period are mentioned in the last section, Lifeways and Symbolic Aspects of South Asian Cultures.

Limitations created by dating force the juxtaposition of Mesolithic and Neolithic cultures of South Asia with little clear distinction in chronological relationships. Sri Lanka's Mesolithic assemblage, characterized by the presence of geometric microliths, has been dated to $28,510+2150 /-1710$ B.P. or contemporaneous with what is designated as the Upper Paleolithic period of Europe, and it contrasts sharply with similarly dated European lithic traditions. According to Deraniyagala (1998:279), the microliths fashioned from quartz into small (less than $4 \mathrm{cms})$ geometric forms in Sri Lanka predate the European samples by some 16,000 years. As stated earlier, the Indian Upper Paleolithic remains an underexplored and little-studied period, so the role Upper Paleolithic stone traditions played in the history of the subcontinent and whether they preceded or overlapped with the dominant Mesolithic tradition remains open to question.

The Indian Mesolithic has been regarded as a particularly active period of human settlement on the continent when a sudden and rapid increase in population occurred in central, northern and western India (Misra 2001 : 498). So far the oldest date for this period-around 12,000 B.P., based on radiocarbon dates-has come from Pune in western India. At Bhimbetka, the Mesolithic period has been dated to $7790 \pm 220$ B.P. (Misra 2002:122-123). This site, where stone tools assigned typologically to the Lower, Middle, and Upper Palaeolithic periods as well as Mesolithic have been found, has proven particularly difficult to date. Consequently skeletons from this site could not be included in Kennedy's ordination figure (discussed later).

While parts of peninsular India reveal burgeoning Mesolithic cultures, Neolithic culture evolved in the northwest of the subcontinent. Dating of the early levels of this single site in South Asia, Mehrgarh, is problematic. The earliest levels of Aceramic Period IA have now been dated to 7000 B.C. (C. Jarrige 2005:27), rendering it contemporaneous with the Peninsular Mesolithic tradition. This site situated in the Baluchistan province of Pakistan reveals development of farming and animal domestication by Period IB, dated to 6500 B.C., but Mehrgarh lasted well into the third millennium B.C. and was culturally closely linked with many other (more than one hundred) Chalcolithic sites that emerged in Baluchistan during the sixth through third millennia B.C.

To summarize, the South Asian, especially Indian stone tool evidence points to a long and continuous sequence of settlement and technological development, without long periods of absence of hominid activity right up to modern times, notwithstanding the fact that even when a large number of sites have been identified, dating is poor and archaeological methods of analysis have fallen well short of what is required to construct a more meaningful picture of cultural sequences 
and what the tools mean in terms of actual lifeways. Turning now to the skeletal record, the discussion emphasizes a similar lack of both secure dating and the type of rigor and comprehensive analysis that would allow us to evaluate human and archaeological remains as component parts of changing human behavioral systems.

\section{THE BIOLOGICAL ANTHROPOLOGICAL RECORD}

\section{Early Hominids in South Asia}

So far the physical (skeletal) evidence for the presence of the actual stone tool makers has been provided by only one specimen, the right half of a skull found in the central Indian state of Madhya Pradesh. This hemi-cranium (Fig. 1) found on the banks of the Narmada River was widely believed by local scholars to belong to a $H$. erectus male. Kenneth Kennedy, who examined this specimen in detail, not only identified the individual as a probable female, but along with the discoverer Arun Sonakia, felt that it did not fit into the morphometric characters of $H$. erectus. Applying multivariate statistical methods to a large comparative sample, Kennedy and his American colleagues demonstrated that the Narmada specimen did fall within the set of characteristics that are found in hominid specimens of the Middle Pleistocene known as archaic Homo sapiens (including preNeanderthal or ante-Neanderthal specimens from Europe and Africa). Dating this specimen has proved difficult, but a range of $0.25-0.15$ mya has been proposed.

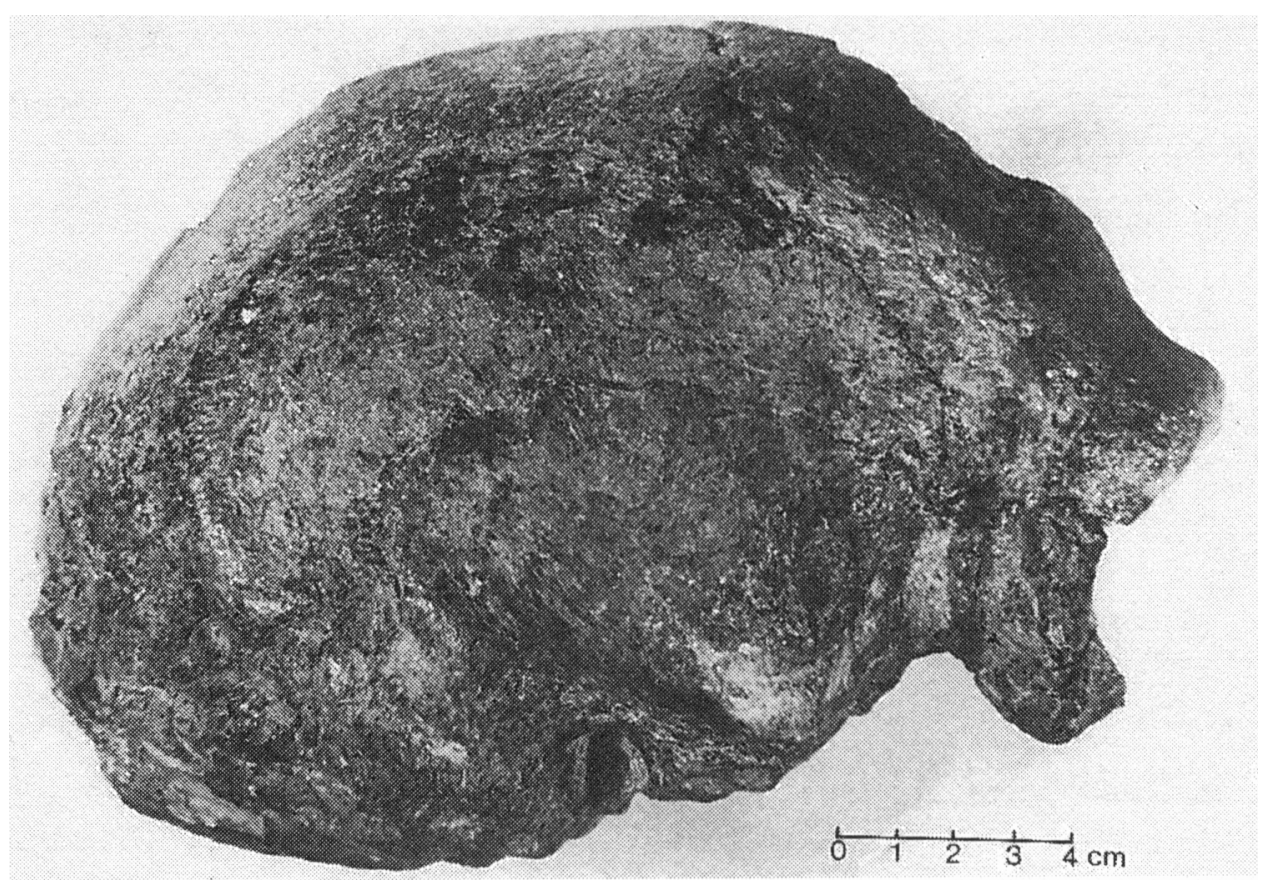

Fig. 1. The Narmada Cranium. Right half of hominid skull discovered in Narmada Valley, central India (from Kennedy 2000; reproduced by kind permission of Anthropological Survey of India). 
The stone tools found in the adjoining area suggest a synchronicity with the late Acheulian tradition. The faunal fossil specimens such as molars of elephant, suid, hippopotamus, equid, and bovid species studied by D. A. Hooijer (1963) suggested a date of late Pleistocene although the possibility of their Middle Pleistocene antiquity could not be ruled out (Kennedy 2000:178-180).

This very careful and detailed assessment has been ignored by anthropologists writing on human evolution from a global perspective. Klein (Stringer 2002:570) and Rightmire (James and Petraglia 2005:56) both have classed this calvarium as belonging to Homo heidelbergensis. As far as this writer has been able to establish, neither of the two scholars have had the opportunity to examine the specimen. In addition, apart from Africa, China also has been shown to have evolving forms from $H$. erectus to the "archaic" type of H. sapiens (Brown 2001:141; Stringer $2002: 570$ ). Therefore, based on geographic distributions, it is not possible to determine at this stage where this hominid might have originated. The dating of the fossil to $250,000-150,000$ B.P. places it very close to other specimens classed as archaic Homo sapiens. It is the writer's opinion that this specimen is far too close in evolutionary terms to the anatomically modern man of around 100,000 to be classed as a Heidelberg type.

Kennedy has questioned the need to introduce a new taxon $H$. heidelbergensis, the name of which derives from a single mandible found in Germany (Kennedy $2000: 62$ ). On the other hand, Chris Stringer holds the view that after H. erectus, $H$. heidelbergensis became a geographically widespread and diverse species that gave rise to $H$. neanderthalensis in Eurasia (Stringer 2002:568). Note should be made that Eurasia is used in a loose sense here, since the farthest east Neanderthal remains have been found is the Middle East and Central Asia, but in rapidly declining numbers. Stringer proposes that the successors of $H$. heidelbergensis were the European Neanderthal and of the African archaic Homo sapiens, modern humans who later spread to the rest of the world. This scheme however leaves the East and South-East Asian (China and Java respectively) skeletal record out of any scenarios concerning migration and evolution. The time line for the African form of archaic Homo sapiens, according to Stringer, is based on the recent redating on the Florisabad cranium to 260,000, Guomde (Kenya) to 150,000 kyra and Singa (Sudan) to 133,000 B.P. This time line or chronology is crucial for the present discussion, as modern humans are thought to have evolved in Africa around 100,000 years ago with fully developed features of modernity (Stringer 2002 :564). The evolutionary line of $H$. heidelbergensis terminating in the European Neanderthals who eventually died out, in my view, should not be projected to the South Asian, East Asian, and Southeast Asian specimens.

Anatomically modern humans first appear in South Asia (Sri Lanka) in the Upper Palaeolithic, the sole exception being the discovery of a skull fragment (temporal bone) in Darra-i-Kur, a cave in northern Afghanistan. The tentative radiocarbon date of $30,000 \pm 1900-12,000$ B.P. was applied because the small amount of charcoal found had to be mixed with clay and then the clay burnt (Dupree 1972:13). Lawrence Angel of the Smithsonian Institute, after trying several reconstructions, felt that "the temporal would fit into a partly Neanderthal population like Skhul just as well as a modern one." Angel's measurements and comparison with Neanderthal and modern samples can be found in his seminal paper on this specimen (1972:54-56). 


\section{Modern H. sapiens in South Asia: The Out of Africa Connection}

The stone tool evidence for the arrival of modern humans in South Asia comes from Sri Lanka where small flake tools were discovered in the coastal alluvial gravels and dune sands (with thermoluminescence dates of 74,000-64,000 B.P. and 28,000 B.P.). But the earliest Sri Lanka skeletal remains are of Upper Paleolithic age, dated to around 34,000-12,000 B.P. through radiocarbon methods and found at three sites (two caves, Batadomba lena and Beli lena Kitulgala, and one rock cliff depression, Fa Hien) (Kennedy 2000:180-188). Some skeletal remains were dated to 24,000 B.P., but the most well-preserved and well-analyzed skeletons at Batadomba lena cave were radiocarbon dated to 15,830 $\pm 680 / 540$. Kennedy, after examining the human remains, concluded that the late Pleistocene inhabitants of Batadomba lena were generally contemporaries of the fossil hominids recovered from outside South Asia at the French sites of Cap Blanc, Chancelade, Les Hoteaux, La Madeleine, and Mas d'Azil, from the Cheleux and Goyet caves of Namur in Belgium, and from Oberkassel in Germany, all of Upper Paleolithic/late Pleistocene antiquity.

According to Kennedy, phenotypically the ancient residents of Sri Lanka had become isolated and do not share morphometric similarities with the people of Peninsular India and the northwestern sector of the subcontinent (see later in Fig. 3). When comparing another set of ancient remains from Betadomba lena with the modern people of Sri Lanka, he found many craniometric similarities between the aboriginal Vedda and ancient Sri Lankans (Kennedy 1965:184-201). Kennedy feels that this apparent isolation is also reflected in the fauna of Sri Lanka, which still remain localized to the island and show little evidence of migration from the Indian subcontinent. Indian fauna (tigers, antelope, hyenas, equines, flying lizards, king cobra, and anthropoid apes) are missing from the Sri Lankan record. The anatomical characteristics of these human specimens from the Upper Palaeolithic era show wide variation: features of robusticity, thick cranial vaults, and large mandibles are found alongside a cranial capacity range of 919.66$1098.87 \mathrm{~cm}^{3}$ in one female to $1500-1600 \mathrm{~cm}^{3}$ in one male. However, all of the skeletons studied by Kennedy also reveal features that identify the population as belonging to anatomically modern $H$. sapiens, including the shape of the skulls, the cranial capacity, and the prominent chin on the mandibles.

This appearance of anatomically modern humans in the southern tip of South Asia fits very nicely with the latest archaeological and genetic evidence for an Out of Africa exodus in its outline, but the picture is far from complete. Chris Stringer, pioneer of the Out of Africa dispersion of $H$. sapiens thinks that the archaeological evidence from Eritrea offers support for a coastal migration of modern man taking a South Asia-Southeast Asia route (Fig. 2) toward Indonesia and Australia: "Middle Paleolithic people might have spread from Africa along the shorelines of Arabia and into Southern Asia during, or soon after, the last interglacial. Continuing along the narrow shorelines, to which they were already adapted, they could have progressed all the way to Indonesia at times of low sea levels ... but from the Australian evidence it must have been before 60,000 years ago" $(2000: 27)$.

As stated earlier, we do not have skeletons of similar antiquity in the rest of South Asia, and without taking into consideration the unbroken stone tool 


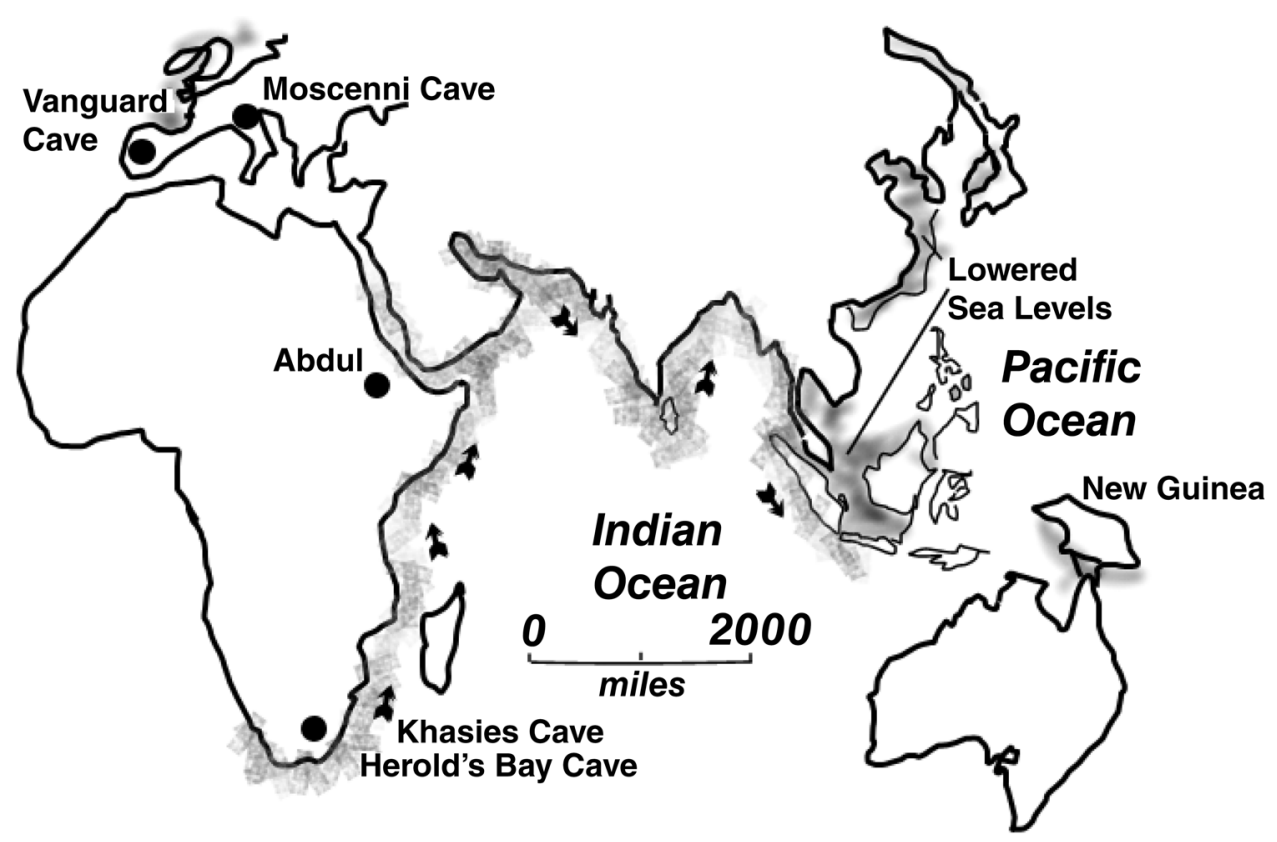

Fig. 2. Out of Africa Migration. Proposed route of coastal migration based on archaeological evidence along the Arabian and Asian coasts toward Indonesia (after Stringer 2000).

tradition, we are left with a hiatus in the skeletal record. Did the inhabitants of Upper Paleolithic and Mesolithic India come from elsewhere and does the anthropological evidence distinguish them sufficiently from the Sri Lankans of the Upper Palaeolithic, which Kennedy thought had become isolated? If, according to Stringer, the ocean levels were low enough to enable Africans to have walked across continents, then the present $25-\mathrm{km}$ shallow strait between India and Sri Lanka should not have posed an obstacle. The Indian landmass was connected to Sri Lanka on many occasions due to fluctuating ocean levels, the last time around 7000 B.P. (Deraniyagala 1998:277). However, the stone tool evidence and the faunal evidence suggest that, despite the shallow strait separating the two landmasses, Sri Lankan and Indian populations did not mix.

The similarity in the physical appearance and skin pigmentation of the Vedda (the aboriginal people of India designated as "tribal" people), the residents of Andaman Islands of the Indian Ocean, the hunters of Papua New Guinea, and the aborigines of Australia, has led to these diverse people being denoted as Proto-Australoid. This group is hypothesized to have been isolated during the process of human advancement toward food production and social complexity due to their hunter-gatherer lifeways; they became "the primitive wild men." Obeyesekere, ${ }^{1}$ reviewing the history of Veddas, alludes to the European fascination with this concept (in reality a myth), which led even Linnaeus to classify humans into Homo sapiens and Homo monstrosus and that influenced John Wesley into conceiving these "savages" as wild men, who were not fully human. Frizzy hair, thought to be an identifying feature of the "Proto-Australoid" set, is not 
uncommon amongst Indian populations, especially in the south and is encountered in tribal foragers as well as settled people. Modern people of South Asia are generally dark skinned as compared to western Eurasia. Herodotus considered Indians similar to Ethiopians, ${ }^{2}$ an observation that most certainly relates to people from the northwestern sector of the subcontinent, the provinces of Punjab and Sindh in Pakistan.

The role of skin pigmentation in the human evolutionary process has received little attention and merits some deliberation. According to Joblin and colleagues (2004: 408), there are readily identifiable adaptive reasons for changes in skin pigment: while primates and apes have white skin covered in black hair, during the course of human evolution, the adoption of bipedal gait and metabolic requirements of a larger brain demanded mechanisms for heat dissipation. The skin, after losing hair in this process would have had to become pigmented in order to be protected from the damaging effects of ultraviolet radiation. It has been proposed that like the early hominids, anatomically modern man was originally dark skinned. Whether the loss of skin pigmentation took place in response to adaptation to the cold climate of the northern regions during the glacial periods, or independently, is not presently possible to establish. However, better knowledge of the time it takes for such adaptive changes to occur would go a long way in settling the debate on human origins and diversity.

Palaeontology cannot confirm this, but the genetic time frame does suggest a branching off of many daughter lineages from a hypothetical "Eve" in Africa no more than 200,000 years ago. The oldest maternal DNA, also known as mitochondrial DNA (mtDNA), is found concentrated in sub-Saharan Africa and has been assigned letter "L." Although population genetics has little bearing on phenotype (physical appearance), the distribution of various genetic imprints in the world population provides us with another useful measure for the spread and distribution of humans and is taken up in the section on genetics.

\section{Humans in Late Pleistocene/Holocene India}

The long hiatus in the South Asian skeletal record from the Upper Palaelolithic Sri Lankan people to the Ganga Plain human remains in early Holocene leaves the question of external peopling of South Asia wide open. Kennedy's graphic illustration (Fig. 3) based on principal component analysis is the best source we have on this subject. This single diagram, incorporating material from widely different eras, is constructed using data from a skeletal series Kennedy had personally examined. However, many skeletal remains could not be included in the study due to their poor preservation, notably some from Mehrgarh. Since Kennedy's work, new discoveries of human remains from some previously known and recently re-opened Chalcolithic sites such as Shahi-Tump (Buquet 2005:58) and Sohr Damb (Franke-Vogt 2005 : 67) are likely to add to the existing anthropological data. Their analysis once published should enhance our understanding significantly. Kennedy's comparative analysis may be difficult to replicate, however, as currently all excavations in Pakistan are being conducted by archaeologists from several different countries. Comprehensive analysis of skeletal remains from a number of Indus sites may also not appear even when reports on excavations, 


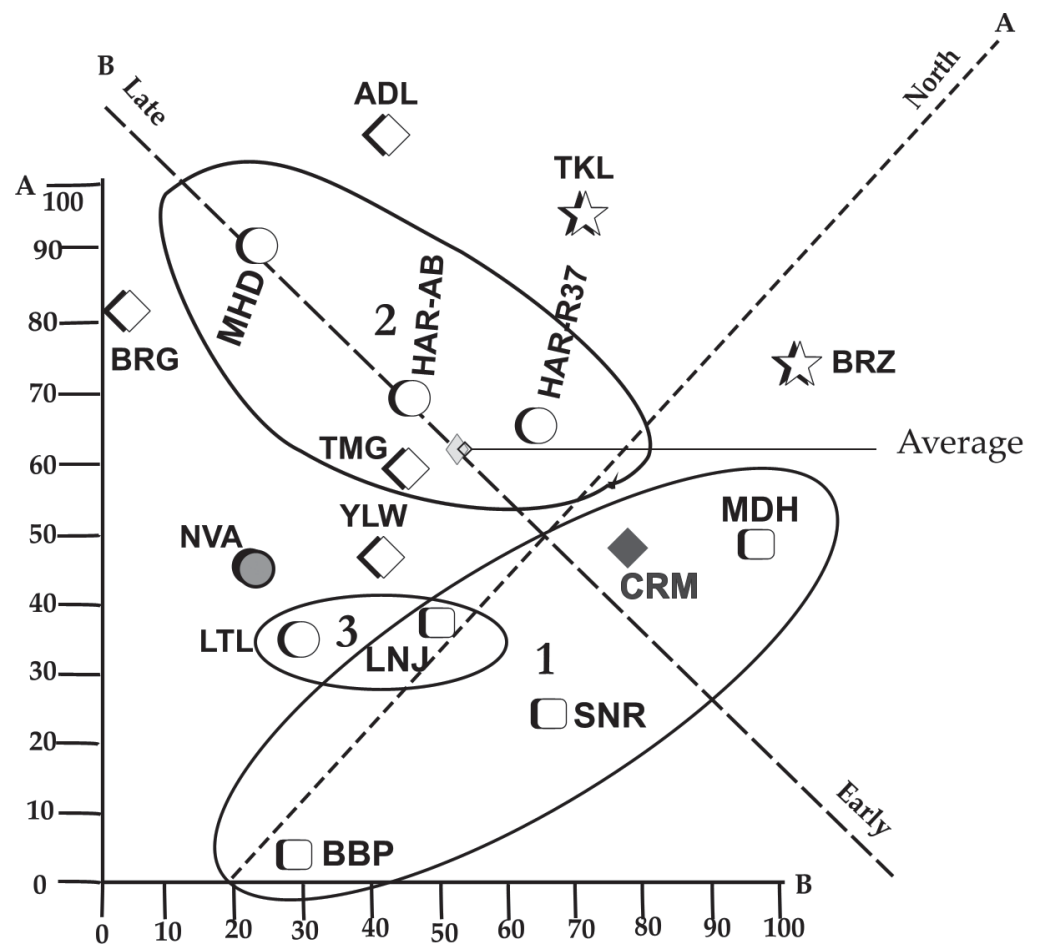

\begin{tabular}{|c|c|c|}
\hline \multicolumn{3}{|c|}{ Key to Figure 3} \\
\hline ᄃ & Mesolithic & $\begin{array}{l}\text { BBP_Bellabandi Palassa (Sri Lanka). 5th mill. B.C. } \\
\text { LNJ_Langhnaj (Gujerat, India). } 4^{\text {th }}-3 \text { rd mill. B.C. } \\
\text { MDH-Mahadaha (Ganga Plain, India). 7th mill. B.C. } \\
\text { SNR-Sarai Nahar Rai (Ganga Plain, India). 7th mill. B.C. }\end{array}$ \\
\hline $\boldsymbol{x}_{3}$ & Neolithic & $\begin{array}{l}\text { BRZ-Burzahom (Kashmir). 2nd mill. B.C. } \\
\text { TKL-Tekkalakota (South India). 2nd mill. B.C. }\end{array}$ \\
\hline C & Harappan & $\begin{array}{l}\text { HAR-AB-Harappa Area AB. 3rd mill. B.C. } \\
\text { HAR R37-Harappa, R37. 3rd mill. B.C. } \\
\text { LTL-Lothal (Gujerat). 3rd mill. B.C. } \\
\text { MHD-Mohen-jo daro. 3rd mill. B.C. }\end{array}$ \\
\hline & Iron Age & $\begin{array}{l}\text { ADL-Adittanalur (south India). A.D. } 1150 \pm 100 \\
\text { BRG-Brahmagiri (south India). Protohistoric. } \\
\text { TMG-Timargarh (Pakistan). 2nd mill. B.C. } \\
\text { YLW-Yeleswaram (south India). Protohistoric. }\end{array}$ \\
\hline C & Chalcolithic & NVA-Nevasa (west India). 2nd mill. B.C. \\
\hline & Cro-Magnons & CRM-European Upper Paleolithic. \\
\hline
\end{tabular}

Fig. 3. Prehistoric populations of South Asia. Prinicipal Component Analysis of South Asian skeletal series (adapted from Kennedy 1992:69). 
long overdue, are finally published, for the simple reason that there are very few well-trained biological anthropologists in India who have the skills and expertise to carry out these kinds of studies.

Regarding the arrangement in this Principal Components Analysis ordination carried out by Kennedy (and replicated here), Kennedy states, "It should be emphasized that this particular ordination was chosen not for a priori mathematical reasons, but based on information on geography and chronology known to the researcher but not the computer" (1992:68).

In the current author's opinion, the fact that the Iron Age people are situated furthest away from the Upper Palaeolithic Sri Lankans is strong proof of phenotypic variation affected by evolutionary adaptation over time. As there seems to be lack of continuity between the Sri Lankan microliths and Indian stone tools of the same period, a direct entry of $H$. sapiens from Sri Lanka would seem unlikely. Instead a South-East Asian route, suggested by the genetic picture, would be a better fit in providing an explanation of the difference and distance between Upper Palaeolithic Sri Lankans and Indians. Sri Lankans, one would assume, did not change, as they lived in an environment that was relatively stable, whereas populations coming to India would have experienced a significantly more diverse range of environments.

As can be seen in Component 1 of Figure 3, the Palaeolithic people of Sri Lanka are at the bottom of the graph and separated from the people clustered in Component 1, which includes the Ganga Plain cohort and the Cro-Magnons of Palaeolithic Europe. Therefore, the ancient South Asians of the Upper Palaeolithic period would seem to have been anatomically different from the Europeans of the same era. The Ganga Plain Mesolithic culture has been dated (AMS) to the early stages of the Holocene $(8865 \pm 65-8640 \pm 65$ B.P.) for Damdama and thus forms the oldest set of fully preserved human fossils in India (Lukacs and Pal 1996:305). Detailed study of skeletons from a neighboring north Indian site, Lekhahia-ki-Pahari, also dated to between $8370 \pm$ and $8000 \pm 75$ в.P. by AMS awaits publication despite over 3 decades having elapsed since their discovery.

Skeletons from three sites in the Ganga Plain, Mahadaha, Sarai Nahar Rai, and Damdama, are physically very similar and are thought to have been closely related. These people with tall and robust skeletons lived a settled (semi-sedentary) hunting-foraging lifestyle. Kenneth Oakley of the Natural History Museum in London, looking at photographs of these skeletons, remarked that they looked like "European Cro-Magnon skeletons" (2000:226) (Fig. 4). Lukacs (2003:329) feels that these north Indians were taller than other Mesolithic populations of Eastern and Western Europe.

The similarity of the Ganga Plain people with the Upper Palaeolithic CroMagnons is thought to be superficial. Both Kennedy and Lukacs feel that the physical characteristics of the Ganga Plain population were a result of biological adaptation to the hot and arid environment (Kennedy 2000:231; Lukacs and $\mathrm{Pal} 2003$ :329). Skeletons from two Mesolithic sites farther south appear different on morphometric analysis. Bhimbetka in central India (not plotted due to dating uncertainties) is perhaps the most important site. Craniometric features of Mesolithic Bhimbetkan skeletons appear similar to the Iron Age settlers of south India, with broad noses and wide palates (platyrrhinic, brachystaphaline), and they are thus different from the people of the Ganga Plain, although the revised dating of 


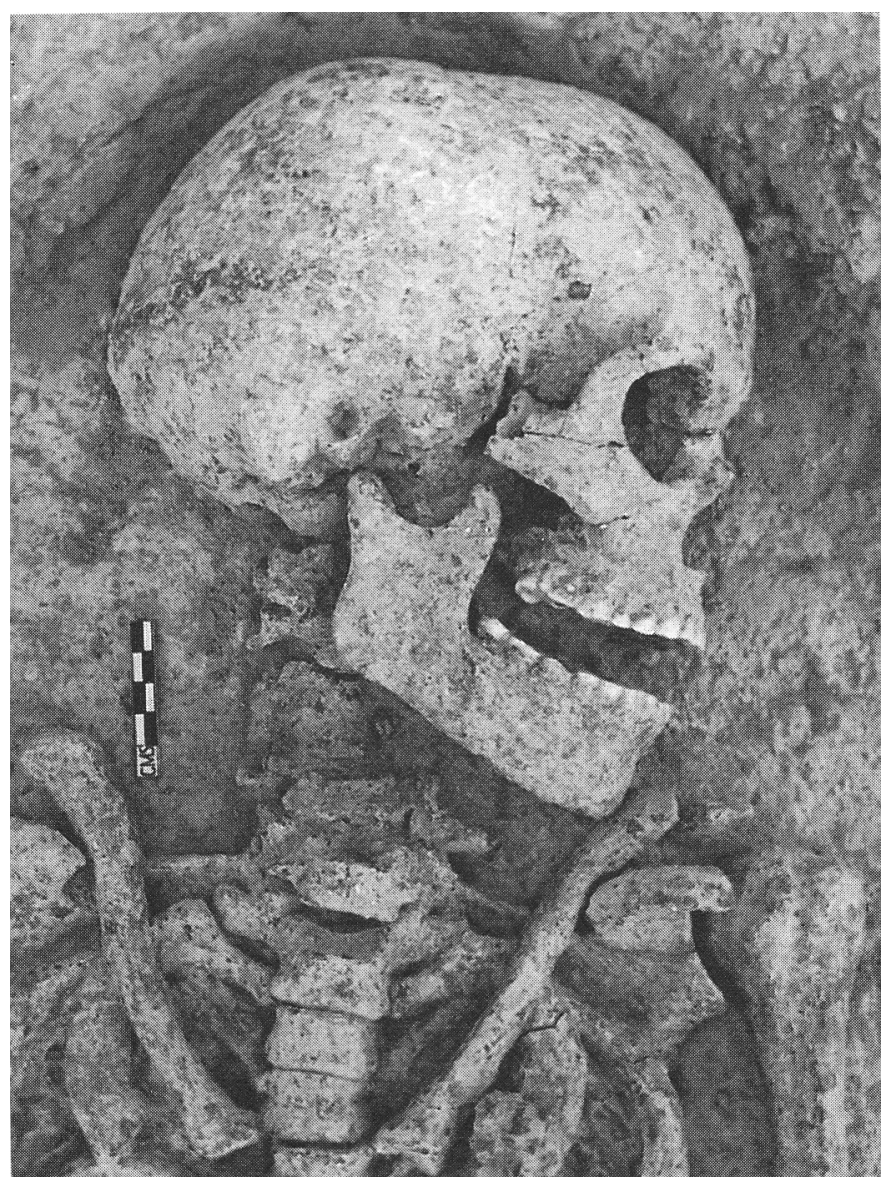

Fig. 4. Skeleton from Mahadaha. Tall robust people found at three Mesolithic sites in the Ganga Plain, north India were likened to the Cro-Magnons of Europe by Kenneth Oakley (from Kennedy 2000; reproduced with kind permission of Department of Ancient History, Allahabad University).

this site places them fairly close to the Ganga Plain time frame (see above). Missing from this analysis are many skeletons discovered in the late nineteenth or early twentieth century that were either badly preserved or lost.

Component 2 of Figure 3 shows that Langhnaj, in the western Indian province of Gujerat, falls just outside the cluster of Mesolithic Ganga Plain people and the European Cro-Magnons (Component 1). The population from Lothal, one of the large Indus coastal cities, is very close to Langhnaj both morphometrically and geographically. The Langhnaj inhabitants, thought to be hunter-foragers, have been dated to $2495-2180$ B.C. (calibrated ${ }^{14} \mathrm{C}$ ). Some 14 skeletons from this unstratified site had deteriorated considerably by the time Sophie Ehrhardt examined them. She disagreed with the German-trained Indian anthropologist who had identified them as Aryans. To Ehrhardt, the human specimens looked similar to the Natufians of Palestine, ancient Egyptians, and Mesopotamians, the cohort to her representing an Asiatic Proto-Mediterranean group. One fully intact skeleton, excavated in 1963, was examined in detail by Kennedy. Kennedy found that this 
dolichocephalic male of about 25-30 years of age had a broad nose, pronounced alveolar prognathism, and a relatively large and robust mandible. Teeth were of moderate size with a surprisingly high incidence of caries $(8 \%)$ for a hunterforager, which placed him in a sedentary hunting-foraging community with a high carbohydrate diet and a close relationship with farmers (Kennedy 2000:235; Lukacs 1990).

The populations in Component 3 in Figure 3 belong to the later Chalcolithic cultures of the Indus region in the northwestern part of the subcontinent (Pakistan). Situated further up the early-to-late and south-to-north axes, these Chalcolithic populations are surrounded by still later populations belonging to the Iron Age cultures with a very wide geographical distribution. The significance in the phenotypic difference between the Chalcolithic people from Harappa and Mohenjo-Daro, two major Indus cities and the population from Lothal, another Indus city, cannot be emphasized strongly enough. Genetically the populations of modern western provinces of Gujerat are closer to the modern people living in Sindh and Punjab provinces of Pakistan where the Indus cities were situated. More recent historical events (invasions) of the last 2500 years could more than account for the slender presence of western genetic material in these areas (Kivisild et al. 2003:329). It is worth pointing out that the admixture of western genetic material in these populations is similar to the populations of the northeast, who share a genetic profile with their neighbors.

The surprising and unexpected discovery of large cities in Sindh and Punjab in the 1920s led British archaeologists like Marshall and Stein to look for western influences. Chalcolithic period cities showing all the hallmarks of an advanced civilization could not have developed, according to these scholars, without the influences of major civilizations of the Near East which were already well known. The skeletons from Mohenjo-Daro were classified by the anthropologists of the time into four distinct racial types, including Mediterranean, Alpine, Mongoloid, and the Proto-Australoid (Piggott 1950:145-147). When he was in charge of the Archaeological Survey of India, Mortimer Wheeler saw the jumbled human remains at Mohenjo-Daro as evidence of an invasion by superior Aryans who had chased the fleeing dark-skinned Dravidians to their death. Wheeler's opinion from the 1940s thus became the defining evidence for the sudden destruction of the Indus Civilization by invading white-skinned Aryans, an opinion he was unwilling to let go even after it had been rendered untenable by George Dales (Dales 1964:43; Wheeler 1968:126-134). Reopening of the Indus sites by American archaeologists in the last three decades has led to major revision of the chronology and a total rejection of the thesis that this civilization came to a traumatic end as a result of a military conquest. Also the skeletons found at MohenjoDaro, which appeared phenotypically distinct from other Indus people, are now thought to represent people belonging to a post-Harappan period (Kennedy 2000:304). In a further Principal Component Analysis (Fig. 5), Kennedy found that this group sat closer to a cohort from ancient Egypt than other Indus people.

The fact that all of the populations falling within Component 3 are surrounded by Iron Age people from different parts of South Asia establishes a close phenotypic link between them, the stratification within the PCA diagram supporting wide diversity and phenotypic variation, a result of adaptive adjustment driven by varied environment and lifeways. The idea that either the founders of the Indus 


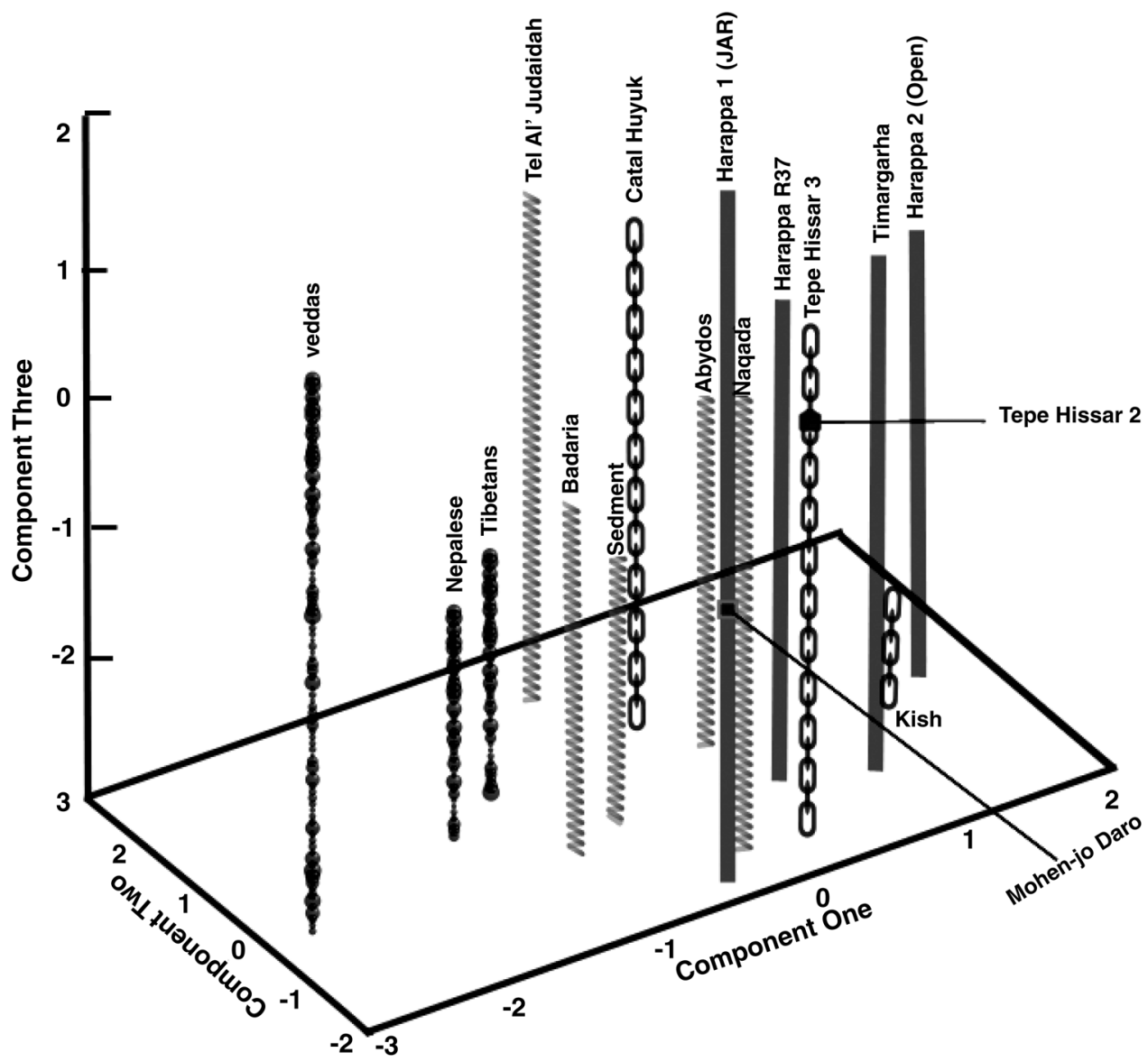

Fig. 5. Morphometric comparison of South Asian and Near Eastern ancient populations. Apart from the recent figures from Kennedy (solid bars); all other measurements are derived from studies conducted in the early decades of the twentieth century (beaded lines—south Asia; coiled lines-Egypt; chains - Near East). See end notes for details (adapted from Kennedy 1995).

Data sets used in Figure 5 for the South Asian and Near Eastern skeletal series. South Asian figures for Tibetans (25) and Nepalese (56) are from Morant 1924. Veddah's from Sri Lanka (62) studied by Osman Hill, 1941. Egyptian series: Naqada (407)-Fawcett and Lee 1901; Abydos (47)-Morant 1925; Badaria (58)-Stoessiger 1927; Sedment (70)-Woo 1930. Near East: Çatal Huyuk (12) and Tell al-Judiadah Syria (19) - Krogman 1949; Tepe Hissar (Iran) II and III (16 and 138)—Krogman 1940 (from Hemphill, Lukacs, and Kennedy 1991).

Civilization or others speaking an Indo-European language came at some stage from outside continues to infect and color scientific discussions and viewpoints. Kennedy, on the other hand, has been unable to find any evidence for a major discontinuity in the skeletal record during or after the mature Harappan period of the Indus Civilization (Kennedy 2000:304).

Similarly archaeology has been unable to find evidence of an intrusive culture that had a major impact on the evolution of South Asian cultures, which started at Mehrgarh and lasted without interruption for well over 6000 years (Kennedy 1995:60; Kenoyer 1998:174; Possehl 2002:175, 250; Shaffer and Lichtenstein 2005:93-94). As a matter of fact, both Possehl (2002:29) and Kenoyer 
(2006:25-29) have classified the evolution of these cultures as one, the Indus Age or the Indus Tradition, dividing the various stages into eras. It would be fair to add that all subsequent cultures of South Asia show more than a trace of influence of this culture which originated in Mergarh in the eighth millenium (Lal 2002; Possehl, pers. comm. ${ }^{3}$ ).

One group of scholars, by putting forward evidence in support of a "slow infusion" of an alien phenotype from the west, has challenged Kennedy's findings of no loss of continuity (Hemphill and Lukacs 1993). John Lukacs, whose important contribution to the dental anthropology of ancient South Asians as well as physical anthropology of some Ganga Plain skeletons is widely acknowledged, in collaboration with Hemphill in 1991 and 1993, proposed evidence for such an intrusion. Their conclusions were based on the dental disease patterns of the Neolithic population of Mehrgarh period IB (6500 B.c.) and Chalcolithic period III (4500 B.C.). The authors found a similarity in the dental disease pattern of the Neolithic Mehrgarh set with the Mesolithic people of Ganga Plain of north India. The dental disease pattern of period III Mehrgarh of some 2000 years later was then compared with other populations of South Asia, notably the Indus Civilization people (2600-1900 B.C.). Similarities were found and a correction factor utilized to adjust for tooth loss during life (AMTL). Once corrected, a match was established between Chalcolithic Harappa and Mehrgarh of 2000 years earlier and the correlation seen as strong enough evidence to lead to the following proposals: (1) that the Neolithic Mehrgarh people were similar to the Ganga Plain people of north India; and (2) that the increasing dental pathology in Mehrgarh III period population suggested a phenotypic shift from Neolithic Mehrgarh due to an infusion/intrusion of western (Mediterranean) phenotype. The consensus of archaeologists specializing on South Asia, it seems, was not considered important for this proposed connection. Also not explained was the size of this intrusion and how, if it occurred over a couple millennia, it would have effected such a transformation. Although Lukacs had suggested adaptation to a changing diet as cause for the dental disease in an earlier paper (Lukacs and Minderman 1992:170), this idea was abandoned in the two papers discussed here. Pascal Sellier, commenting on the mortuary and funeral architecture at Mehrgarh, was unable to find any major shift in either the culture or funerary methods. Changes were noted between the Neolithic and Chalcolithic period, but they were considered no more than what was to be expected in a changing society (Samzun and Sellier 1985:92; Sellier 1992:255).

Hemphill and Lukacs also included a Principal Component Analysis figure based on univariate measurements made in the early decades of the twentieth century, comparing Near Eastern with South Asian populations (Hemphill et al. 1991). Affinities were established on the strength of this analysis and with a conviction that Mehrgarh had had trade contacts with Shahr-i-Sokhta and may have come under the ruling or dominating influence of Elam. They failed to observe that Shahr-i-Sokhta had not even come into existence at the time of Mehrgarh period III. The authors had labored under several mistaken assumptions such as South Asia having been at some stage the recipient of "superior racial stock" from Tepe Hissar (Hemphill et al 1991:174). In a later paper, the same group of scholars used Hegelian logic and visual anthropology to suggest that the current population of Punjab was certain enough evidence of such a Mediterranean 
contribution (Hemphill and Lukacs 1993:115). No wonder this idea of slow intrusion based on dental disease has failed to receive support from Kennedy (2000:280) and Kenoyer (2005:28). Hemphill and Lukacs had not used Kennedy's up-to-date findings in their PCA figure. Kennedy produced another PCA figure using his up-to-date data in 1995 (1995:51) (Fig. 5).

The proximity of the Middle and Near Eastern populations to the Indus people should be taken into account with the knowledge that people from Nevasa in western India also share the same affinity. Besides, the proximity of various skeletal series in this ordination gives no hint as to the direction of movement of populations, if there ever was any. The proposals of an infusion or intrusion by Hemphil and Lukacs may have relied on the attempts of archaeologists like Stuart Piggott and others who had tried to connect the pottery motifs found at several pre-Indus sites with Tepe Hissar and other Near Eastern sites. (Piggott 1943, 1950). Such links, once considered strong evidence of influence and intrusion, are no longer regarded as proof of such events, rather no more than a result of trade and other forms of human contact.

In order to support a shift or change in the prevailing indigenous culture caused by intrusion, the evidence has to be of a magnitude the kind of which has not been encountered in South Asia. This approach and method of assessing the evidence very much forms the backbone of modern archaeological thinking and practice whether relating to South Asia or the rest of the world. The Indian genetic picture discussed next also offers no clues as to any major intrusions; instead it offers perhaps the strongest support for the same continuity attested to by the anthropological and archaeological record.

\section{GENETICS OF MODERN HUMANS OF SOUTH ASIA}

Stringer's prophetic views quoted above were confirmed by a recent genetic study in which the mtDNA ${ }^{4}$ evidence pointed to a rapid settlement along the Asian coast toward Indonesia and Australia (Macaulay et al. 2005 :1036). The genetic profile of the inhabitants of the Andaman Islands in the Indian Ocean (Thangraj et al. 2005:996) also lends firm support to this coastal migration. The $M$ group of maternal DNA, which is younger than the sub-Saharan African mtDNA (L3), has a wide presence from the Indian subcontinent to South-East Asia and East Asia as far as Papua New Guinea. The discovery of the oldest wellpreserved anatomically modern human in Australia dated to about 62,000 B.P. (Joblin et al. 2004:294) has made this route and time frame the basis for this migration.

The age or time depth of this mtDNA group $M$ is said to be around 60,00070,000 years B.P. What is strange in relation to the African connection is that there is very little trace left of this DNA in Africa, as though it were completely eliminated there or more than likely evolved outside Africa. Younger in age DNA groups such as $\mathrm{N}$ and its daughter $\mathrm{R}$ are also present in sizeable numbers in South and East Asia. Western mtDNA on the other hand is composed of many sub-branches and groups derived from N and R. Richards and colleagues (2000, 2002, 2003) have looked at the European, Near Eastern, and Arabian, as well as African links closely and have been unable to find a single migration out of Africa that could explain the distribution of mtDNA in western Eurasia. Achilli et al. 
(2004:914) have more recently shown that the European component (H1) of the most widespread mtDNA in the west- $\mathrm{H}$ - and lineage $\mathrm{V}$ are quite young and have dated them to terminal Pleistocene and early Holocene.

Kivisild and colleagues $(2003: 327)$ were the first to point to South Asia, in particular the Indian subcontinent, which according to them played a pivotal role in the late Pleistocene genetic differentiation of the western and eastern Eurasian gene pools. Further, Metspalu and colleagues (2004) went on to point out that the age of $\mathrm{M}$ and $\mathrm{N}$ branches of the maternal DNA, including $\mathrm{R}$-daughter of $\mathrm{N}$-is greater in India than elsewhere (Table 2).

Another study by Chinese geneticists working in India was able to establish the entry of the root for the $\mathrm{R}$ haplogroup in India around 64,200 \pm 6300 years ago (Palanichamy 2004:975). The authors say that although the state of the $\mathrm{N}$ macrohaplogroup is not fully established, they estimate a younger date of arrival of this mutation in India, around 49,000 \pm 7,900 years ago. Importantly they conclude that South Asia to East Asia would have been a single route of passage for modern humans and suggest that the arrangement of the two haplogroups studied ( $\mathrm{N}$ and R) and their daughters does not support a "two wave" scenario. The reader is reminded that, until the publication of these studies, geneticists were suggesting a two wave migration: the first early wave of $M$ haplogroup migration taking the coastal route to Australia, the second younger wave containing mainly R haplogroup lineages, heading toward Europe via the Middle East. Palanichamy and colleagues have also shown that of the 15 daughter lineages of $\mathrm{R}$ only 5 are found in west Eurasia, with the rest in India, East Asia, and Oceania. Of the 8 subhaplogroups of $\mathrm{N}$ only 3 are found in the West.

The question of the direction of spread of modern man emerging from Africa can also be addressed by looking at the concentration of the number of DNA groups (haplogroups) in a given location. The sub-Saharan African populations hold very few mtDNA haplogroups, suggesting that the most ancient mtDNA haplogroup L has evolved to only a few lineages within the same parent mtDNA family. The distribution of the total number of major haplogroups when plotted along their geographical distribution gives us further insight into the direction of spread of the descendants of the oldest L haplogroup (Fig. 6). As can be seen the total number of major haplogroups in South and parts of East/South-East Asia remains low, less than four haplogroups per location. The total number of haplogroups begins to rise as one goes farther north in East Asia (only a small section of populations from China has been included in this analysis) and farther west in South Asia. The overall mtDNA haplogroup count remains highest in western Eurasia with the exception of the Swedish (six), Volga Finns, and the Cornish (seven each). The same trend, of high haplogroups counts, is also seen in northern Africa, suggesting that northern Africa and most of west Eurasia have been populated by a far greater admixture of younger more recently derived daughters of macrohaplogroup $\mathrm{N}$ and subhaplogroup R. Unlike South and South-East Asia, only haplogroup $\mathrm{H}$ reaches frequencies higher than 50 percent in western Eurasia, all other western mtDNA lineages holding much lower frequencies (below 20\%).

This analysis is based on figures provided by five studies (see legend to Fig. 6 and Table in appendix), with the 2004 Metspalu et al. study contributing the main body of evidence for South and Southeast Asia as well as China. The gradient or cline in the percentages of $M$ haplogroup represents a spread of this DNA 


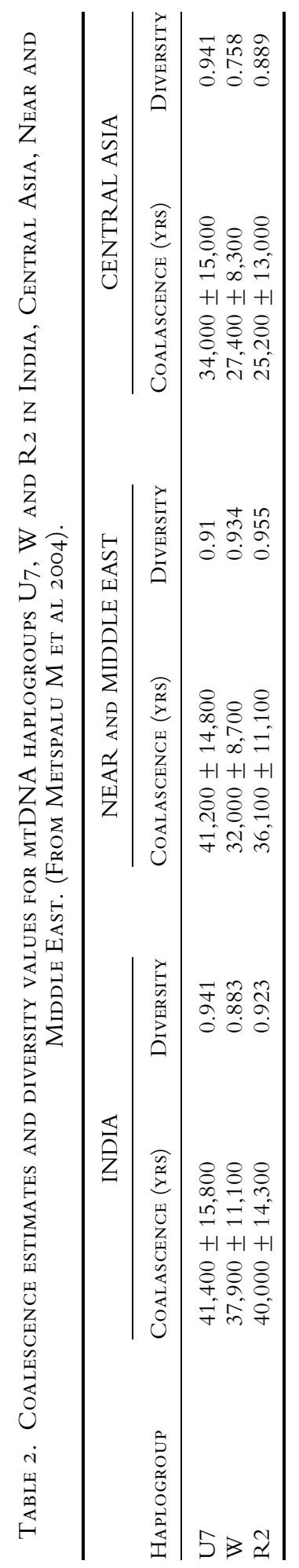




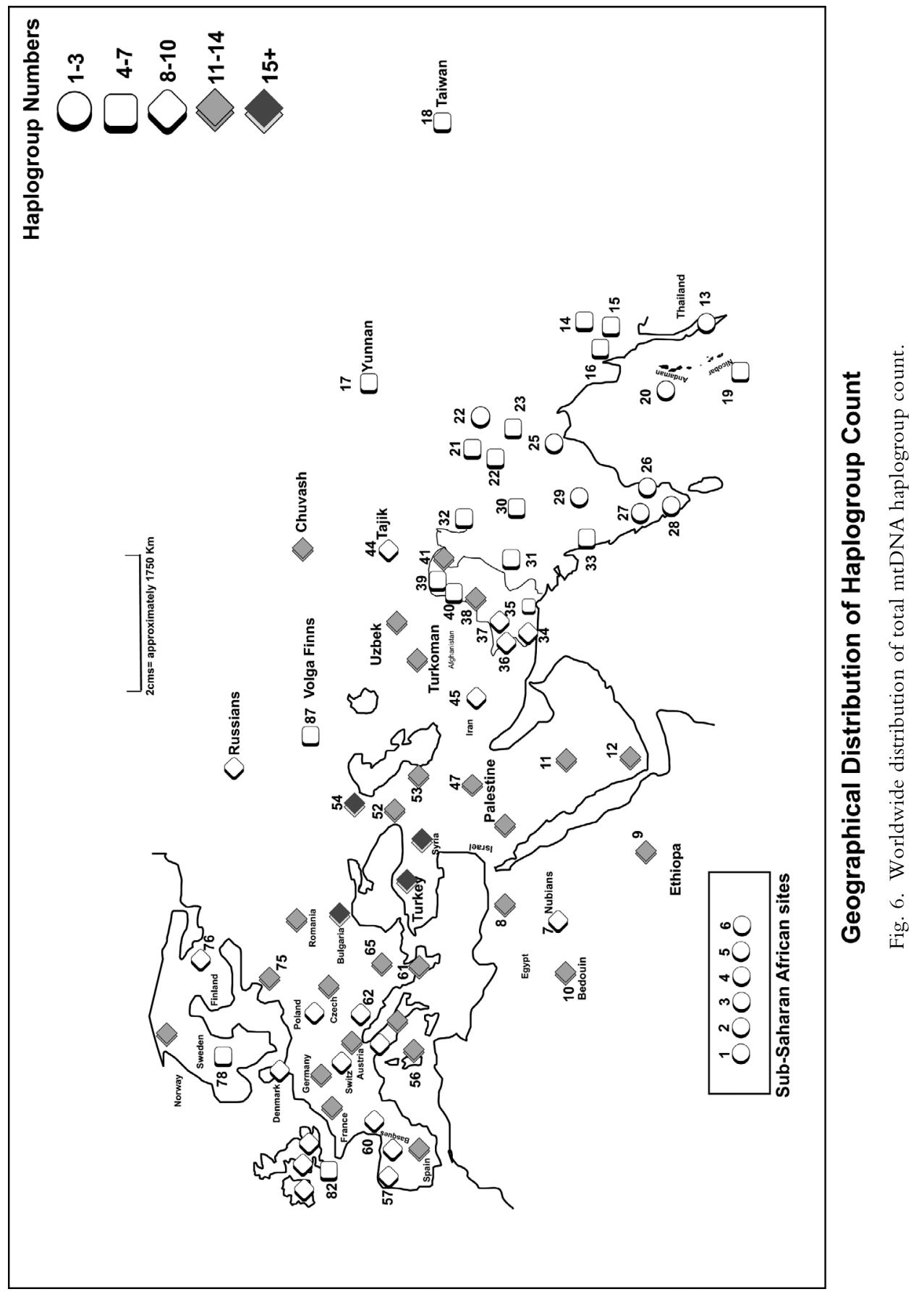


lineage from coastal areas in the Indian Ocean such as Thailand to the eastern provinces of India and then the rest of India. Frequencies farther inland in Thailand and China do not reach such high figures. ${ }^{5}$ These figures support Kennedy's conclusion that, for some reason, the Upper Palaeolithic Sri Lankans did not cross into the Indian subcontinent. This genetic cline does help us understand the break in Sri Lankan and Indian lithic traditions. Unfortunately we do not have physical anthropology correlates for this assumed route of passage. More evidence is required not only from eastern India, which still remains under-researched, but also countries such as Myanmar, Thailand, the Malay Peninsula, and the Indonesian islands. Lukacs (1987) did suggest links with South-East Asia on the strength of dental measurements, but at this stage these are proposals that need more robust support from physical anthropology and archaeology.

Using this genetic evidence for entry of modern man into Asia, note should be made of Peter Brown's observation in relation to the colonization of China by modern man. China boasts a rich collection of early and intermediate forms of hominids from $H$. erectus to archaic Homo sapiens, but then the skeletal record suddenly stops until the Holocene. Brown suggests that the widespread distribution of the "distinctive" East Asian cranio-facial morphology appears by the early Neolithic (Brown 2001 : 144). Presumably, Brown considers this typical East Asian phenotype to have evolved from the migrating "Out of Africa" modern humans. One can only hope that further search for fossil evidence will help bridge the gap although it should still be possible to establish, on the basis of the cultural leads embedded in the Neolithic skeletal evidence, whether these "new arrivals" were intrusive or indigenous.

\section{LIFEWAYS AND SYMBOLIC ASPECTS OF SOUTH ASIAN CULTURES}

Western geneticists, alerted to the presence of mtDNA haplogroup $M$ in high concentrations in South Asia, turned their attention to the genetic profile of the tribal populations of Peninsular India. Indian populations have been traditionally divided into tribal or the aboriginal hunter-gatherer groups, and the large settled Hindu society stratified into castes. This approach assumed that the "backward" aboriginal hunter-gatherers classed as tribes in India were probably the original $M$ gene carriers. The people belonging to the Hindu caste system, in contrast, were thought to have migrated from outside, bringing new languages (Dravidian and Indo-European) and higher intelligence with them. Initial claims that the Indian genetic profile fell neatly into these pigeonholes have not received support from recent well-conducted studies. The pioneering studies of Kivilsid et al. (2003) and Metspalu et al. (2004) have looked at large sections of Indian population subgroups. Achieving high sample sizes, they were able to establish that the genetic profile of both the caste and aboriginal tribal groups are virtually identical. In particular, no language-based distinction could be seen in the genetic profile of either the northern or the southern caste or tribal groups. The unbroken sequence of stone tools, much in need of more dedicated research, brings to the fore the possibility of evolution of $H$. sapiens locally from the Archaic form discovered in the Narmada Valley. However, the genetic evidence as we have it, speaks to the contrary: the arrival of migrants from Africa sometime in the region of 60,000 to 70,000 years ago. 
James and Petraglia (2005:S4) have listed the markers of this package of symbolic behavior that Klein had suggested in $2000^{6}$ and sought to find similar evidence in South Asia. The fact that the present genetic profile of modern west Eurasians cannot be traced back to the Cro-Magnons (Stringer 2002:570) blows a hole in this "superior" gene concept, which is said to have appeared on the scene with a crash, especially since the thrust of the scheme was meant to place the European man as the provider of superior intellect to the rest of the world. Besides, mutations that appear de novo (out of the blue) without exception have a deleterious and damaging effect on the organism. James and Petraglia have built their negative assessment on a perceived relative absence of the same symbolic behavior markers in South Asia.

As hinted earlier the evolution of South Asian cultures may have taken a very different path and direction, divergent enough to make any attempt at finding an exact match with the European cultures unworthy of merit. South Asians for instance may have used different, more perishable materials for self-decoration and for artistic aims. Until recently, large communal meals were served on platters made from dry leaves stapled together with toothpick-like sticks. Bowls to hold liquids were made in a similar fashion and can be seen even today in roadside stalls. Self-adornment with flowers, once again is as popular now as it would have been in ancient times. This tradition can most certainly be traced back and is well represented in the Buddhist as well as the much older Indus period art.

Ancient Sri Lankans, who crafted geometric microliths, successfully exploited both the avian and aquatic resources as remains of freshwater shellfish, fish, birds, reptiles, and mammals have been found alongside the geometric microliths of the Upper Paleolithic period (Kennedy 2000:182). Ostrich egg decorations (PataneMaharashtra, western India; Sali 1985 :144), harpoon fashioned from bone (Fig. 7a) (Belan Valley, U.P. north India; Sharma 1970) and evidence from south India that the Upper Palaeolithic people knew the use of fire, exploited plant parts, and probably fished using net sinkers like modern tribal people are some examples of symbolic behavior spread over a wide expanse of the country around $30 \mathrm{kyr}$ B.P. (Raju and Venkatasubbaiah 2002:97,100). James and Petraglia mention these items including an Upper Paleolithic shrine, a platform with a triangular stone placed in the center discovered by Mark Kenoyer in the Son Valley in U.P. north India (Fig. 7b). Many of the painted rockshelters in central India are situated around caves, which in most instances have been turned into temples. Often a shape or form in the rockface is painted red, representing the image of a deity, and worshipped.

The rapid rise in population in India at the Pleistocene/Holocene boundary mirrors a similar population explosion in the Fertile Crescent. Caution needs to be exercised here as the Indian Mesolithic dates, few and far between as they are, most certainly represent an underestimate. Poor stratification caused by disturbance in layers of occupation, virtual absence of organic matter, and limited availability of better dating techniques constitute major stumbling blocks. For example, one skeleton examined by Kennedy (Bhimbetka III-A-28a-5) most probably came from an Upper Palaeolithic cultural layer, but this site was never dated.

The burgeoning population in the Fertile Crescent seen as a solitary and single event in world history was used as a model for "deemic diffusion" by Renfrew (1987) and others like Peter Bellwood (2005). According to this view the Fertile 

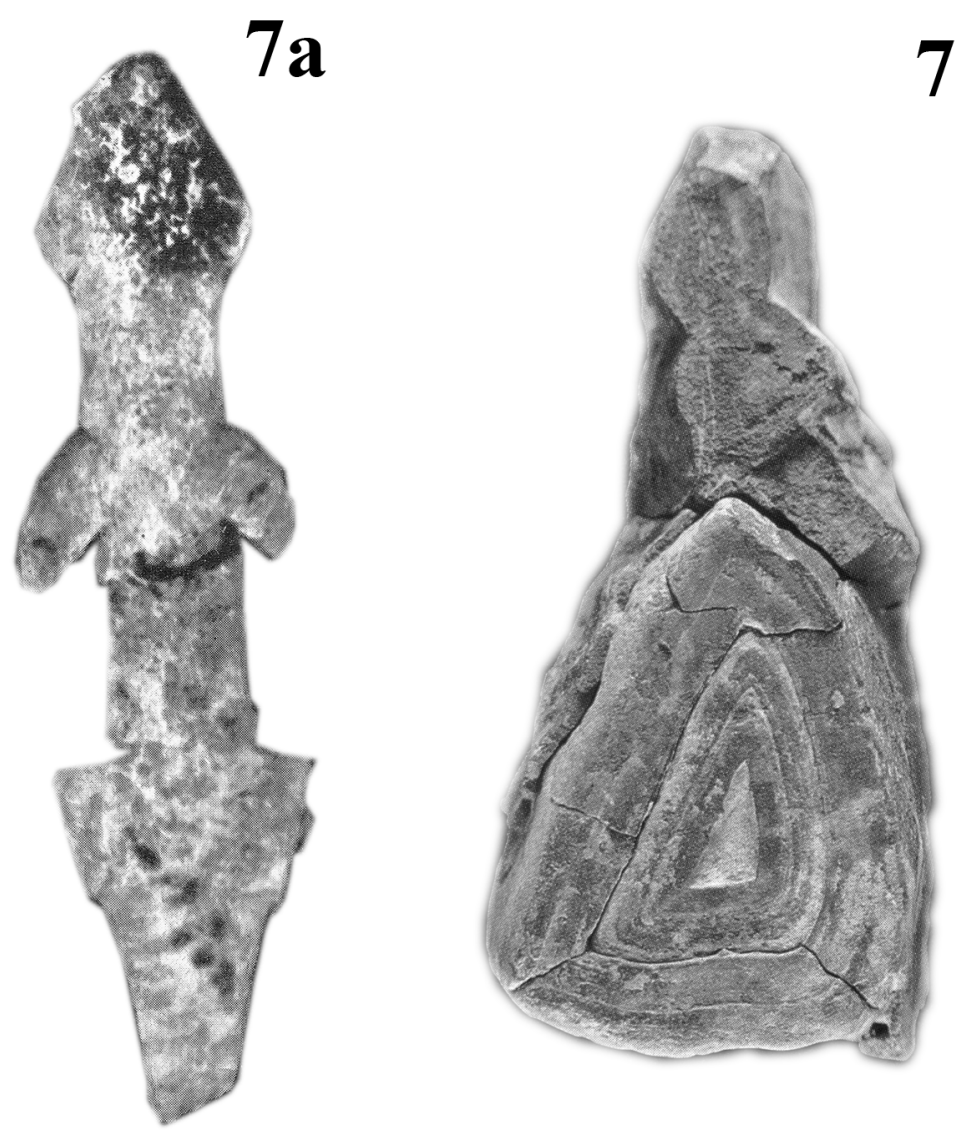

Fig. 7. a. Upper Palaeolithic bone harpoon from Belan Valley, north India dated to 30,000 B.P. (from Archaeological Survey of India 1977). $b$. Votive stone figure from an undated Upper Palaeolithic site in Son Valley, north India.

Crescent's overflowing population colonized the rest of the world in a single sweep, spreading in an orderly fashion carrying with it farming technology and an entirely new language. Graphic illustration of such a spread can be found in some of the latest publications on the subject (Bellwood 2005:7; Joblin et al. $2004: 301-302)$. Renfrew tentatively suggested that perhaps the early farmers of Mehrgarh also spoke Indo-European languages (1987:208). Under attack from historical linguists he revised his views, changing his initial migration theme from one language to two (see Renfrew in Joblin 2004:310). Peter Bellwood, modifying Renfrew's ideas, has asserted that farming spread through India with a "heavy plod" as India lacked the "quick smart" hunter-gatherers of the west (2005:96). This point of view fails to take into account the influence of the local Palaeoenvironment on the lifeways of Mesolithic Indians. The evidence from India points to an entirely different society, of a people who subsisted on easy availability of large mammals through most of the late Pleistocene well into Holocene as far as the protohistoric times. 
Evidence from three geographically distant sites offers tangible insights into how people managed their life. Not included in this discussion are Loteshwar, Kili Ghul Mohammad, and Bagor. Like the Ganga Plain sites discussed shortly, Loteshwar and Bagor were both occupied for over a millennium during the microlithic phase. Calibrated dates have recently been offered for Loteshwar from the early eighth to the sixth millennium B.C. and for Bagor I from mid-sixth millennium to mid-fifth millennium B.C. (Patel 2008:128). Both of these sites reveal occupation from an Aceramic microlithic phase to a Ceramic Chalcolithic phase. Kili Ghul Mohammad is another site thought to have achieved pastoralism in the fifth millennium B.C. (Fairservis 1956:356-357, 1975:136).

Three closely situated sites in the plains of River Ganga (Ganges) belonging to a Mesolithic culture have already been described. The tall and robust people living at these sites are thought to have led a semi-sedentary life in communities of substantial size. Theirs were relatively large settlements: $8750 \mathrm{~m}^{2}$ (Damdama), $8000 \mathrm{~m}^{2}$ (Mahadaha), and $1800 \mathrm{~m}^{2}$ for Sarai Nahar Rai (Misra 1996:247), occupied by an estimated population of 550-650 individuals for Damdama and 7001000 for Mahadaha (Lukacs and Pal 1993:749; Robbins in press). Also at Damdama some 30 species including fish, mollusk, and bird were recorded (Thomas et al. 1996:257), while at Mahadaha a separate butchering plot was used (Kennedy $2000: 203)$. At Damdama, a hearth near each burial and the construction of a burial tumulus above the grave were considered novel developments. Burnt wild animal bones belonging to the rhinoceros, gaur (Indian bison), elephant, and hog were found mingled with burnt human bones (Kennedy 2000:203-205; Thomas et al. 1996:257). From a symbolic perspective two elongated bone arrowheads and an ivory pendant with two holes bored on either end were found in a single grave at Damdama. At Mahadaha necklaces of bone rings and an ear ornament made from an antler constituted the few burial offerings recovered.

Central India where the now famous caves and rockshelters were discovered by the late Vishnu Wakankar contains a large area of several thousand square kilometers where the hill crests consist of naturally formed rockshelters. Wakankar, concentrating in an area with a high number of rockshelters and caves, was successful in identifying, excavating, as well as copying the mural images at many of these sites. However the size of the area, the fact that much of it is heavily forested and inaccessible suggests that an enormous wealth of material still lies unexplored. Wakankar (1976) found evidence of occupation in Bhimbetka, which he believed went right back to the Lower Palaeolithic. He also recovered stone tools that he believed came from Middle and Upper Paleolithic periods but the Mesolthic period seems to have been best represented at Bhimbetka. The images in the rockshelters portray a people who hunted large mammals like deer, wild cattle, buffalo, elephants, and also rhinocerous (Fig. 8a, b). Erection of a partitioning wall in a cave by using stones as well as stone flooring suggests that these places were used for settled habitation (Misra 1985:39). Discovery of querns and mullers in Bhimbetka as in the Ganga Plain sites also points to knowledge and use of plant parts (Lukacs and Pal 1993:748; Kennedy 2000:205). Due to their size, querns and grinding stones at places such as Ganga Plain sites have been thought to represent markers of a semi-sedentary existence.

Long experience in hunting and contact with wild animals would have enabled these Mesolithic people to understand and befriend some of these species. The 


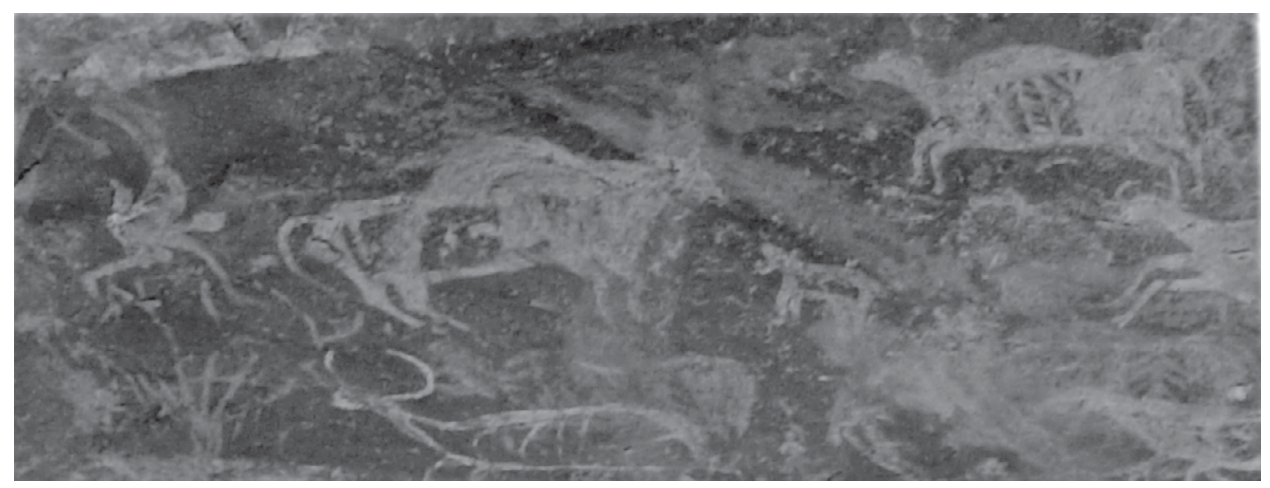

a

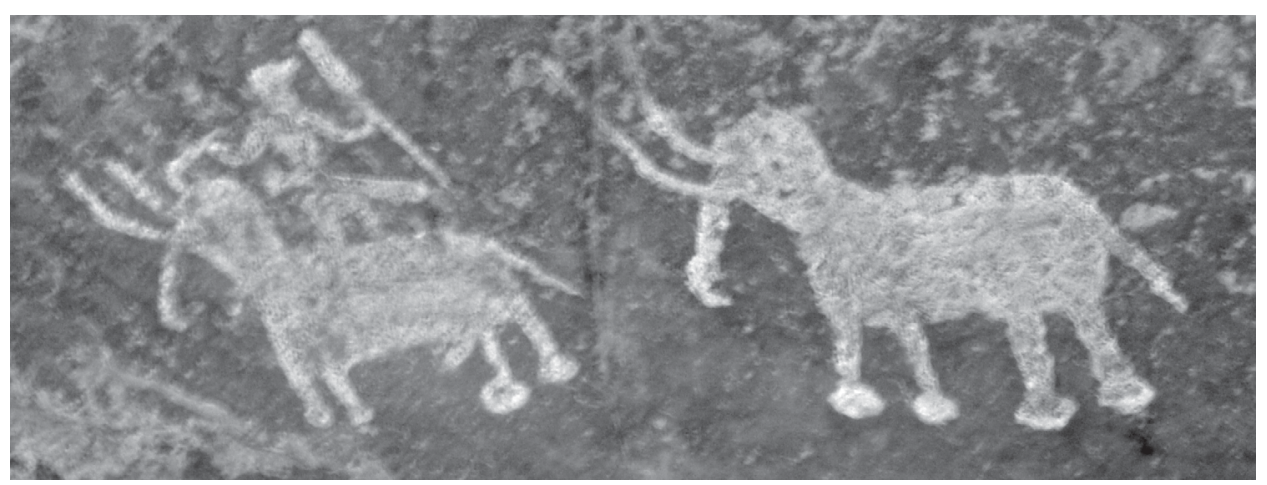

b

Fig. 8. a. Hunting scene from Mesolthic Bhimetka, central India. (Photo by V. Singh 2006). b. Elephant hunt, Mesolthic Bhimbetka, central India. (Photo by V. Singh 2006)

image depicting the sport of "Bull Leaping" (Fig. 9) shows the animal in a seated position, something not expected from a wild animal. Archaeozoologists studying horse domestication in the Russian steppes generally agree that prolonged interaction starting with hunting for food is an essential prerequisite for domestication. At what stage these Meosolithic people became pastoralists and farmers cannot be established but the process most certainly would have been gradual spanning many millennia.

The reader has already been introduced to Mehrgarh in Baluchistan, Pakistan. We do not know about the preceding cultures in the terminal Pleistocene as no archaeological or anthropological information exists for this region. Claims that this "Neolithic" revolution spread rapidly from the Fertile Crescent through the Zagros Mountains farther east can no longer be seriously considered, as in chronology Mehrgarh is certainly not later than the Pottery Neolithic (PN) period of the Fertile Crescent. The dates for the PN, ${ }^{7}$ Mehrgarh, and China coincide to the extent that a transfer or translocation of technology or people cannot be considered possible. Bar Yosef in his masterly review on faunal exploitation in the Fertile Crescent argues that although the domestication of caprids (sheep and 


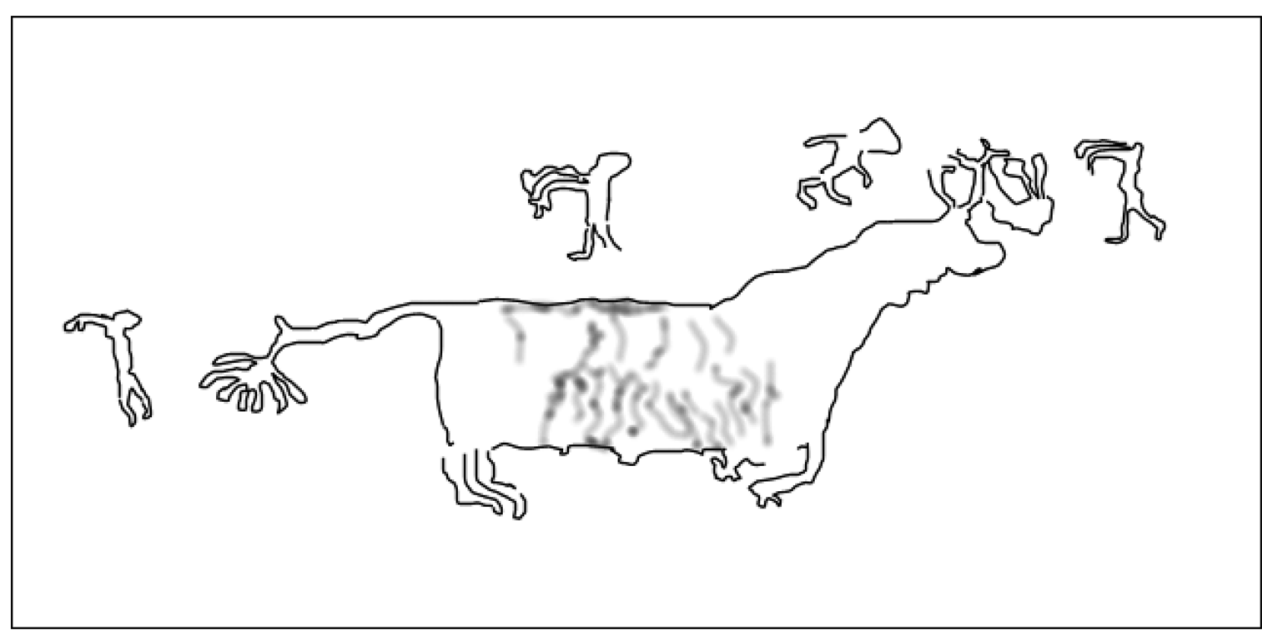

Fig. 9. Bull Leaping: Outline of an image from Mesolithic rockshelter in Narsingarh, central India. The animal, probably Bos indicus, is depicted in a seated pose with decorated tail and horns (?) (Wakankar's reconstituted image on the back cover of his 1976 book shows decorated horns). Figures (probably children) are seen jumping over the animal but the image of the figure close to the horns is indistinct. Others can be distinguished easily. (Photo and line drawing by V. Singh 2006)

goat) first occurred in the Tauraus/Zagros region, pastoral nomadism did not develop before 7500 B.P. (uncalibrated; Bar Yosef 2000:193). Sedentary pastoral status seems to have been achieved at about the same period at Bagor I, Rajasthan (west India) as attested by remains of what are thought to be domesticated sheep and goat (Misra 1973:106), and also Kili Ghul Mohammad. These claims have been challenged by Meadow and Patel (2003), the main criticism centering on faunal identification to species as well as variation in size of the species in question. Classifying wild and domesticated forms on the strength of variation in size of fossil specimens of the same species, problematic even in some expert hands, is another area where lack of specialist training in India has led to findings being questioned.

Evidence for exploitation of the local fauna in both the Aceramic and Ceramic phases of Mehrgarh (Period I) indicates how successful the residents of Mehrgarh were. Richard Meadow has listed the species hunted according to the percentage of the remains found in the pre-pottery levels. A comparison of this list with what Bar Yosef has documented for the Fertile Crescent allows us to evaluate the claims that domesticated sheep and goat could only have come from the west. Ten of the twelve species listed by Meadow (1993:306) are native to South Asia and still survive in the wild. Only wild sheep and goat would have been available to the Mehrgarh population as these two species have not been encountered in other parts of Mesolithic India. Chinkara (Gazella benedetti) tops the list, followed by wild sheep and goat. Barasingha (Cervus duvacelli), Nilgai (Boselaphus tragocamelus), Bos (probaly indicus), water buffalo, and spotted deer (Axis axis) follow in order. Black buck (Antelope cervicapra), wild boar, and elephant (single specimen) bring up the rear.

The fact that by the middle of the seventh millennium domestication of most 
species (sheep, goat, and Bos indicus) had been achieved from their wild forms attests to the presence of wild forms of sheep and goat in the region. The successful domestication of these species also indicates prolonged contact and familiarity.

The French anthropologist Pascal Sellier identified unique side-opening graves dating to about 6500 B.C. at Mehrgarh (revised dating to 7000 B.C.). The structure he later realized was meant for secondary interment. Sellier also mentions similar side-opening graves dating to the end of the fourth or early third millennium in Shahr-i-Sokhta in Iran and Tepe Gawra in Iraq. Another late 2nd millennium site (Sapalli-tepe in Uzbekistan,) was found to have the side opening closed with bricks under a Kurgan (Sellier 1992:259-263). The subsequent evolution of mortuary rituals and spare use of ornaments and mortuary goods at earlier levels has unquestionably an indigenous signature. This trait can be found at all cultural levels throughout South Asia where no individual was ever elevated to a station that required singular treatment at death. This single and perhaps most important character attribute of South Asian people underscores a society, which despite advances and successes, was never driven by military and expansionist aspirations. The best example for this cultural trait is to be found at major cities of the great Indus Civilization. Well known not to contain any instruments of warfare, their total lack of monumental architecture is a feature also recognizable at all preIndus sites of Baluchistan. This single attribute then distinguishes the Indus from the Egyptian and Mesopotamian Civilizations and may have prompted Pigott to remark, "I can only say that there is something in the Harappa Civilization that I find repellent" (1950:201).

A cohesive and complete picture of the cultures of the inhabitants of South Asia before and during the Mesolithic is rendered difficult not only by the sparse and wide distribution of the sites, but also less than exhaustive study of them. During the Mesolithic the use of carnelian for making microlith tools by the Ganga Plain inhabitants (Kennedy 2000) and its use for making beads by the Period III (fifth millennium) residents of Mehrgarh (Barthélemy de Saizieu and Rodière 2005) attest to exploration and utilization of material from over a large part of northern South Asia. North and western India were the sole source of carnelian that later, in Chalcolithic times, was considered a precious stone.

Cultural links and a degree of uniformity are best seen in rockshelter and cave art. Wakankar who had recorded and studied these murals had observed similarity in design and evolution at many sites separated by large distances (Wakankar and Brooks 1976). The fact that mural art cannot be dated matters little; even if some art were to be placed closer to the modern era, that in itself provides proof for a continuity and conservatism spanning millennia.

The impact of Mehrgarh through its Neolithic and Chalcolithic phases on subsequent South Asian cultures was enormous. Many examples of this unbroken tradition can be given despite many invasions, especially within the last 2500 years, but three are chosen as illustrations. The swastika motif (Fig. 10a) first seen on the potsherds from Mehrgarh MR.2 from the first half of the fourth millennium B.C. (J-F Jarrige 1993a: plate 6.12) is seen again at Harappa (seal 118, Fig. $10 b$ [Mahadevan 1977]) in the mature Harappa of mid-third millennium B.C. This symbol still holds a central place in the Hindu religious system as it can be seen painted on village houses, on implements used in religious ritual, and temples throughout modern India. 


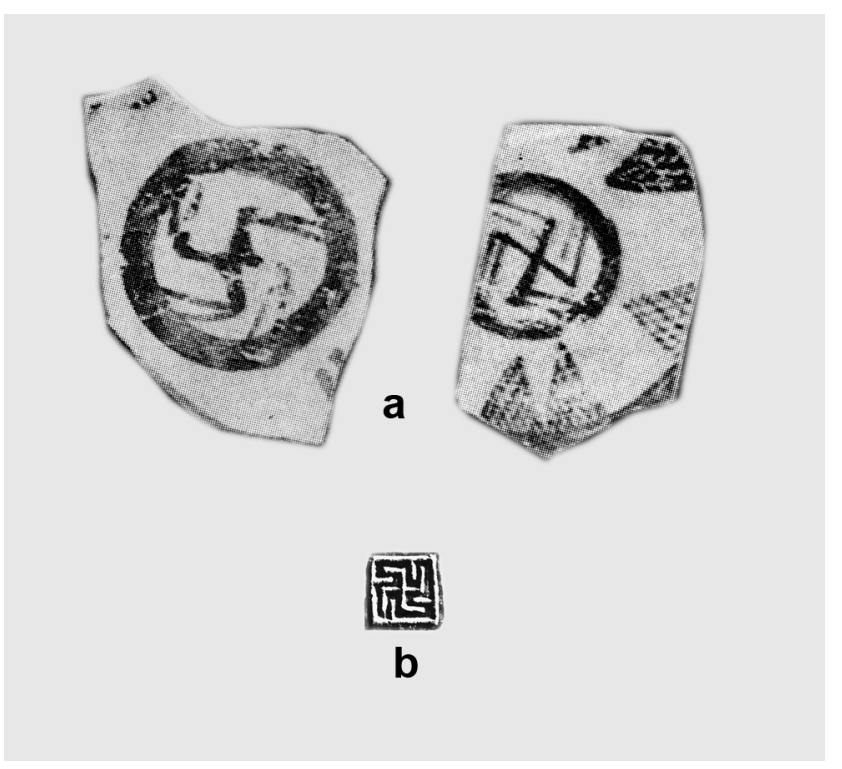

Fig. 10. a. Swastika motif on painted pottery from fourth millennium B.c. Mehrgarh (from J-F Jarrige 1993a, courtesy of Catherine Jarrige, French archaeological mission). b. Seal 118 from third millennium Harappa (from Mahadevan 1971; Archaeological Survey of India).

Images of the zebu bull either painted on pottery or fashioned as clay figurines is also a classical marker of Indian cultures, first appearing at Mehrgarh in the sixth millennium as figurines (Meadow 1987:898) and on fourth millennium Nausharo pottery (Fig. 11; J-F Jarrige 1993b:159). The bull figurines have been found at the majority of sites from pre-Indus, Indus, and post-Indus periods. The bull to this day holds an important place in Hindu mythology and religious beliefs as it did for the Vedic people. Female figurines considered images of goddesses by Aurel Stein ${ }^{8}$ have also been discovered at many Chalcolithic sites. Although bull and female figurines have been associated with the process of Neolithization and therefore not unique to South Asia (C. Jarrige 2005:34-35), it is their configuration that gives them their own identity. The hump of the zebu bull and the pinched birdlike features and large hoodlike headdress of the female figurines, set them apart. To this can be added the decorative use of Peepal leaf (Ficus religiosa), yet another item with an important established place in the Indian cultural and religious system (Fig. 11).

The extent to which the ancient South Asian communities were in contact is illustrated by the appearance of a horned deity on an etched terracotta cake from Kalibangan, one of the large Indus cities situated in Haryana, India (Fig. 12a, b). Wakankar found a similar representation at Bhimbetka linking the Mesolithic culture of central India with a much younger Chalcolithic one in the northwest. This image carries with it influences that go deeper than contacts and probably reflect inherited ideas and beliefs with religious connotations.

Lastly, the subject of the two major languages spoken in South Asia and the question of their arrival from outside can only be discussed here in the most sketchy and brief outline, due to its sheer enormity. The belief that the Dravidian group of languages evolved in the Fertile Crescent and spread to South Asia with farming can now be dismissed as a product of poor scholarship. McAlpin's bold claim that he was able to read the Proto-Elamite script and establish a kinship 


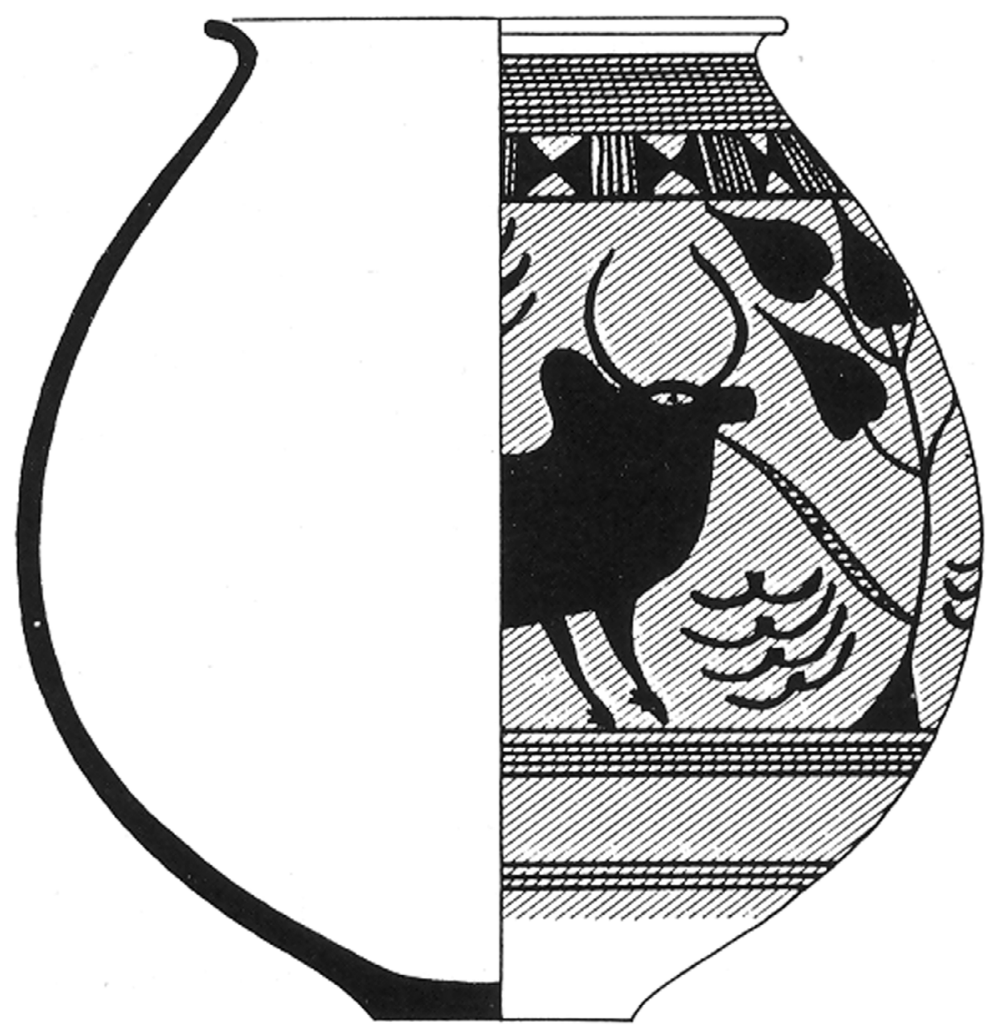

Fig. 11. Zebu bull and Peepal leaf decoration on a vase from Nausharo, fourth millennium B.C. (from J-F Jarrige 1993b, courtesy of Catherine Jarrige, French archaeological mission).

between it and the Dravidian languages stands to this day without foundation, as the Proto-Elamite script has never been deciphered (Englund 2004:104; Potts 1999:79). Bellwood's acceptance for the migration of this language from the Near East (Bellwood 2005:213) after having expressed some circumspection about McAlpin's claim $(2005: 211)$, and then his reliance on "common sense" over the difficulty in marrying transmission of languages and archaeology $(2005: 8)$, is all the more astonishing. No archaeological or anthropological correlates for this migration have ever been proposed although a group of west European geneticists did find support in the distribution of a male Y-chromosome lineage. Quintana Murci and colleagues (2001) suggested that the presence of Y-chromosome lineage $\mathrm{Hg} 9$ ( $\mathrm{J} 2$ in the new classification) in western parts of the subcontinent suggested such a migration around 5200 B.P. Realizing that they had overlooked Mehrgarh having attained full farming status, the same group in another discussion paper (McElreavey and Murci 2005) pushed the date back by some 3000 years. No new evidence was offered for this time shift. Further, the total absence of this lineage from the Dravidian speakers of south India was either not realized or commented on.

The issue of migration of the speakers of Indo-European languages fuels passionate and polarized responses. All that can be said here is that LambergKarlovsky in 2002 critically reviewed the archaeological evidence for the passage 


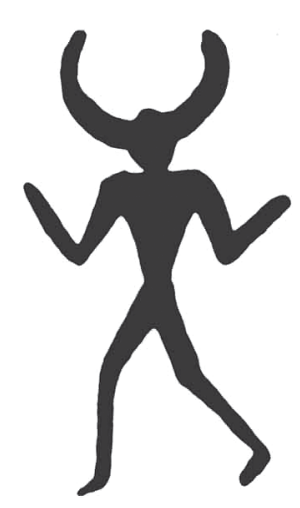

Bhimbetka

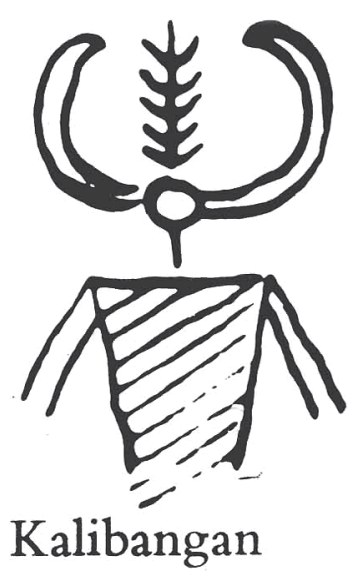

a

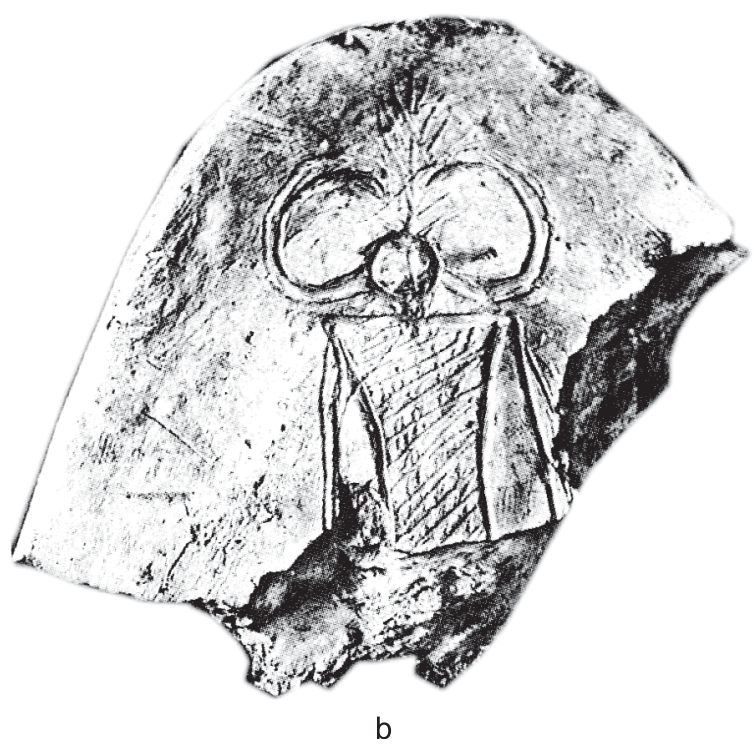

Fig. 12. a. Horned deity Bhimbetka-Mesolithic, central India (hand drawn by Wakankar 1976). $b$. Horned deity figure on a terracotta cake from Kalibangan, one of the third millennium B.c. Indus cities. (From Lal 2002, reproduced with the kind permission of Aryan Publications)

or origin of the Indo-Iranian group of languages in Central Asia (LambergKarlovsky 2002:63-87). His sometimes scathing assessment drew rather unconvincing responses from the supporters of such a migration. The result of this assessment has been that Mallory and Adams in their latest review have accepted that the archaeological evidence for the presence or passage of Indo-Iranians through Central Asia varies from meager to nonexistent (Mallory and Adams 2006:462). The same western European group of geneticists mentioned earlier had also proposed a second migration, this time of Indo-Europeans from Central Asia, carrying with it $\mathrm{Y}$-chromosome lineage $\mathrm{Hg} 3$ ( $\mathrm{R} 1 \mathrm{a}$ in the new classification) 
during the second millennium B.C. They had overlooked a substantial presence of this lineage through most of South Asia, even in the tribal people of south India where frequencies higher than those encountered in other Indo-European language speakers (Greeks and Italians) have been found. ${ }^{9}$ These issues cannot be discussed in detail here but the reader is directed to the most thought-provoking and scholarly critique on the subject, that of the eminent anthropologist Joseph Errington of Yale University, who has termed the field of historical linguistics and the proposed "unilinear" mode for the spread of languages "colonial linguistics”(2008).

\section{DISCUSSION}

The image of South Asia once thought to be a land of fabled riches has undergone many transformations. The current image held in academic circles and consequently in popular imagination finds its roots in the eighteenth- and nineteenth-century unilinear concepts of human evolution. Superiority accorded some populations of the world resulted in racial typing of human anatomy and features, an outdated practice that remains firmly and deeply ingrained in the mind-set of many scientists.

Scientific evidence on the other hand requires a practitioner to purge all such preconceived biases, which sadly in South Asia's case cannot be said to have happened. European renaissance could be blamed for some of these inclinations but it was the emergence of European colonialism during the two centuries referred to above that served to lay the foundation for these concepts. Then the discovery that Sanskrit was closely related to Greek and Latin led to the creation of another "unilinear" entity-the Indo-Europeans. Gordon Childe's now famous and faulty labeling of the Indo-Europeans as "Aryans" gave rise to the creation of a distinctly superior race, which, it was suggested, had overrun the rest of the world. Sciences dealing with the human ancient past since the middle of the twentieth century have attempted to look at various world cultures with a different and more analytic approach. Cultures and the people responsible for them are studied and examined for what they are in place of the erstwhile practice of finding signs of overreaching and external- superior influences. Reopening of the Indus Civilization sites by American archaeologists and the pioneering anthropological work of Kenneth Kennedy has not only provided fresh insights but also transformed our understanding of South Asia's ancient past. The achievements of the French archaeology mission led by Jean-Francois Jarrige in discovering Mehrgarh, and the efforts of a number of dedicated South Asian archaeologists, has further helped to paint an entirely new picture. However, these new directions and insights have not been accepted by many specialists practicing in South Asia and remain unknown to the larger readership.

South Asian cultures for all their strengths and weaknesses remain bona fide South Asian and deserve a respect they have failed to receive. The evidence we have today, both from human remains and stone artifacts, suggests that South Asia need not look to its neighbors with gratitude for either phenotypic (physical) or genetic contributions. As stressed in this essay, substantial evidence exists for the indigenous evolution of cultures and a unique cohesion in this culture as far back as the Mesolithic era. 
Physical anthropology points to a wide phenotypic variation, more than can be shown elsewhere in the world, no doubt a result of adaptation to an environment that varied, but not to the same extent as in western Eurasia. Kennedy's conclusion that the ancient South Asians exhibited considerable diversity in their physical features is backed by genetic evidence for human presence that takes us into the Middle Paleolithic period. The genetic profile of modern inhabitants of South Asia confirms this link with the past, as people in Peninsular India show very little contribution from outside, especially when it comes to introduction of two major language groups: Dravidian and Indo-European. The genetics of modern north India (provinces of Uttar Pradesh and Bihar), which have been the seat of Sanskrit learning for a good 3000 years, shows only a slender presence of western genetic lineages. The same applies to South India where Dravidian languages belong and most probably originated. The expected sharing of maternal and male lineages in the border regions of South Asia is evident to a comparable degree in the east and west. As stated earlier, this sharing of genes in the periphery is not carried through into the Indian heartland. This, then more or less eliminates any possibility of a major influx of genetic material from the west, a theme that pops up time and time again.

Many of the issues discussed here continue to hinder progress in understanding South Asia's past. The heavily politicized issue of Indo-European languages is so far the Achilles' heel preventing South Asia from being allowed to stand on its own two feet.

\section{ACKNOWLEDGMENTS}

Greatest gratitude and thanks are due to Prof. Kenneth Kennedy for his monumental contribution to South Asian anthropology and to South Asia, and for his help in correcting my misunderstanding on a number of anthropological issues. I hope I have presented his views and work faithfully. I am also grateful for advice and help from Professors Possehl, Meadow, and Kenoyer.

\section{ENDNOTES}

Abbreviations used: kyr — thousand years; kyra — thousand years ago; mya — million years ago.

1. G. Obeyesekere, Prof. Emeritus in Anthropology at Princeton, gave a lecture on the history of the Vedda. See reference for the transcript address.

2. Herodotus, Book III: ch-101.

3. G. L. Possehl (pers. comm. 25/8/2008): "I think most of us see continuity in the entire sequence from Mehrgarh 1 to the present in South Asia. There is cultural change and new biological elements are introduced, but not on a scale that most would think of as a break or discontinuity."

4. mtDNA stands for mitochondrial DNA, the DNA carried by females (mothers) within cells and outside the nucleus where the main DNA resides.

5. M lineage frequencies: Trang, Thailand, 100 percent; Andaman Islands, Indian Ocean, 98 percent; Bengal, East India, 87 percent; Kerala, South India, 81 percent; Nagaland, Northeast India, 74 percent; Punjab, Northwest India, 57 percent.

6. Specialized technology (e.g., blades, microliths, and the use of new materials such as bone), overtly symbolic behavior (e.g., art, artifact styles), chronological and geographical variability in artifact styles, artifact standardization, long-distance exchange networks, defined use of space within a settlement and landscape context, and ideas of group and self-identity.

7. Bar Yosef $2000: 186-191$.

8. Periano Ghundai, Kaudani, Moghul Ghundai, Dabar Kot, Sur Jangal (Stein 1929). Kalatuk, Chiri, Kulli, Nokjo Shahdinjai, Mehi (Stein 1931).

9. Author's assessment of the evidence, archaeological and genetic, for the entry of Indo-Europeans into South Asia awaits acceptance by western academic journals. 


\section{REFERENCES CITED}

Achilli, A., Chiara Rengo, Magri, Vincenza, Anna Battaglia, Rosario Olivieri, Fulvio Scozzari, Massimo Cruciani, Zeviani, Egill, Briem, Valerio, Carelli, Pedro Moral, JeanMichel Dugoujon, Urmas Roostalu, Eva-Lis Loogväli, Toomas Kivisild, Hans-Jürgen Bandelt, Martin Richards, Richard Villems, A. Silvana Santachiara-Benerecetti, Ornella Semino, and Antonio Torroni

2004 The molecular dissection of mtDNA haplogroup $\mathrm{H}$ confirms that the Franco-Cantabrian Glacial Refuge was a major source for the European gene pool. American Journal of Human Genetics $75: 910-918$.

ANGel, LAWRENCE

1972 A Middle Paleolithic temporal bone from Darra-i-Kur, Afghanistan. Transactions of the American Philosophical Society. Prehistoric Research in Afghanistan 62(4) :52-56.

BAR Yosef, Ofer

2000 The context of animal domestication in southwestern Asia, in Archaeology of the Near East: 185-195, ed. M. Mashkour, A. M. Choyke, H. Buitenhuis, and F. Poplin. Groningen: ARC Publications 32.

Barthélemy de Saizieu, B., and J. Rodière

2005 Bead drilling: A look from Mehrgarh and Nausharo. Preliminary results of micro-trace analyses, in South Asian Archaeology 2003: 39-48, ed. U. Franke-Vogt and H-J Weisshaar. Aachen: Forschungen zur Archäologie Außereuropäischer Kulturen Band 1.

Biagi, P.

2004 The Mesolithic settlement of Sindh (Pakistan): A preliminary assessment. Praehistoria $4-5: 195-220$.

Bellwood, Peter

2005 First Farmers: The Origins of Agricultural Societies. Oxford: Blackwell Publishing.

Brown, Peter

2001 Chinese Middle Pleistocene hominids and modern human origins in east Asia. http:// www-personal.une.edu.au/ pbrown3/Brown2001.pdf

Buquet, C.

2005 The burial practices at Shahi-Tump (Balochistan, Pakistan): First anthropological analyses, in South Asian Archaeology 2003: 57-62, ed. U. Franke-Vogt and H-J Weisshaar. Aachen: Forschungen zur Archäologie Außereuropäischer Kulturen Band 1.

Dales, George F.

1964 Mythical massacre at Mohen-jo Daro. Expedition 6(3):36-43.

Dennel, R. W., Linda Hurcombe, R. Coard, M. Beech, M. Anwar, and S. ul Haq

19931990 field season of the British Archaeology Mission to Pakistan in the Baroth area of the Pabbi hills, Northern Pakistan, in South Asian Archaeology: 49-64, ed. A. J. Gail and G. J. Mevissen. Stuttgart: Franz Steiner.

Deraniyagala, Siran U.

1998 Pre and Protohistoric settlement in Sri Lanka. Proceedings of the XIII Congress of International Union of Prehistoric Sciences (A.B.C.O. s.r.l. Forli-Italy) 5(16):277-285.

Djindjian, F., J. K. Kozlowski, and F. Bazille

2003 Europe during the early Upper Paleolithic (400000-30000 BP): A synthesis, in Trabalhos de Arqueologica: 33:29-48, ed. João Zilhão, Francisco de Errico. Lisbon: Instituto Postuguês de Arqueologica.

DUPree, LOUIS

1972 Introduction: Prehistoric Research in Afghanistan. Transactions of the American Philosophical Society 62(4): 1-13.

ENGLUND, ROBERT

2004 The state of decipherment of Proto-Elamite, in The First Writing: Script Invention as History and Process: 100-149, ed. S. Houston. Cambridge: Cambridge University Press.

ERRINGTON, J.

2008 Linguistics in a Colonial World: A Story of Language, Meaning, and Power. Malden: Blackwell Publishing. 
FAirservis, WALter A.

1956 Excavations in The Quetta Valley, West Pakistan. Anthropological Papers of the American Museum of Natural History: 45(2). New York: American Museum of Natural History.

1975 The Roots of Ancient India: The Archaeology of Early Indian Civilization, 2nd rev. ed. Chicago: University of Chicago Press.

Franke-Vogt, U.

2005 Excavations at Sohr Damb/Nal in 2002, in South Asian Archaeology 2003: 59-72, ed. U. Franke-Vogt and J. Weisshaar. Aachen: Forschungen zur Archäologie Außereuropäischer Kulturen Band 1.

Hemphill, Brian, and John F. Lukacs

1993 Hegelian logic and the Harappan Civilization: An investigation of Harappan biological affinities in light of recent biological and archaeological research, in South Asian Archaeology: 101-120, ed. A. J. Gail and G. J. Mevissen. Stuttgart: Franz Steiner.

Hemphill, Brian, John F. Lukacs, and Kenneth A. Kennedy

1991 Biological adaptations and affinities of Bronze Age Harappans, in Harappan Excavations 1986-90: A Multidisciplinary Approach to Third Millennium Urbanism: 137-182, ed. R. H. Meadow. Madison, WI: Prehistory Press.

Herodotus

Histories, trans. George Rawlinson. Ware, UK: Wordworth Editions Ltd.

James, Hannah, and Michael Petraglia

2005 Modern human origins and the evolution of behavior in the later Pleistocene record of South Asia. Current Anthropology 46 (suppl.): S3-S17.

JARrige, Catherine

2005 Human figurines from the Neolithic levels at Mehrgarh (Balochistan, Pakistan), in South Asia Archaeology: 27-37, ed. Ute Franke-Vogt and Hans-Joachim Weisshaar. Achen: Linden Soft.

JARRIGE, JEAN-FranCOIS

1993a Excavations at Mehrgarh: Their significance for understanding the background of the Harappan Civilization, in Harappan Civilisation: 79-84, ed. G. L. Possehl. New Delhi: Oxford and IBH Publishing Co. Pvt. Ltd., American Institute of Indian Studies.

$1993 b$ The question of the beginning of the mature Harappan Civilization as seen from Nausharo excavations, in South Asian Archaeology: 149-164, ed. A. J. Gail and G. J. Mevissen. Stuttgart: Franz Steiner.

Joblin, Mark, Matthew Hurles, and Chris Tyler-Smith

2004 Human Evolutionary Genetics: Origins, Peoples \& Disease. Oxford: Garland Science.

Kennedy, Kenneth A.

1965 Human Skeletal Material from Ceylon, with an Analysis of the Island's Prehistoric and Contemporary Populations. Bulletin of the British Museum (Natural History) II (4). London: British Museum.

1992 Biological anthropology of Human Skeletons from Harappa: 1928-1988. Eastern Anthropologist $45(1-2): 55-85$.

1995 Have Aryans been identified in the prehistoric record from South Asia? Biological anthropology and concept of ancient races, in The Indo-Aryans of Ancient South Asia: Language, Material Culture and Ethnicity: 32-66, ed. G. Erdosy. Berlin: Walter de Gruyter.

2000 God Apes and Fossil Men: Paleoanthropology in South Asia. Ann Arbor: University of Michigan Press.

KenOyer, J. MARK

1998 The Ancient Cities of the Indus Valley Civilization. Oxford: Oxford University Press.

2005 Culture changes during the late Harappan Period at Harappa: New insights on Vedic Aryan issues, in Indo-Aryan Controversy: Evidence and Inference in Indian History: 21-49, ed. E. F. Bryant and L. L. Paton. London: Routledge.

2006 Culture and society of the Indus Tradition, in Historical Roots in the Making of "the Aryan": 21-49, ed. R. Thapar. New Delhi: National Book Trust.

Kivisild, Toomas, S. Rootsi, Mait Metspalu, S. Mastana, K. Kaldma, J. Parik, E. Metspalu, M. Adojaan, H. V. Tolk, V. Stepanov, M. Glöge, E. Usanga, S. S. Papiha, C. Cinnioğlu, R. King, Luigi Cavalli-Sforza, Peter A. Underhill, and Richard Villems

2003 The genetic heritage of the earliest settlers persists in both Indian tribal and caste populations. American Journal of Human Genetics 72:313-332. 
KLEIN, RichaRd G.

2000 Archeology and the evolution of human behavior. Evolutionary Anthropology 9:17-36.

Lahr, Marta M., and Robert A. Foley

1998 Towards a theory of modern human origins: Geography, demography, and diversity in recent human evolution. Yearbook Physical Anthropology 41:137-176.

LAL, BRIJ BASI

2002 The Sarasvati Flows On: The Continuity of Indian Culture. New Delhi: Aryan Books.

LAMBERG-Karlovsky, C.

2002 Archaeology and language: The Indo-Iranians. Current Anthropology 43(1): 63-88.

LARICK, ROY

2004 Homo erectus and emergence of Sunda in the Tethys Realm. Athena Review 4(1):32-39.

Lukacs, John F.

1987 Tooth size variation in Prehistoric India. American Anthropologist 87(4):811-825.

1990 On hunter-gatherers and their neighbors in Prehistoric India: Contact and pathology. Current Anthropology 31(2): 183-186.

Lukacs, John F., ANd Lori Minderman

1992 Dental pathology and agricultural intensification from Neolithic to Chalcolithic Periods at Mehrgarh (Baluchistan, Pakistan), in South Asian Archaeology: 167-179, ed. Catherine Jarrige. Madison, WI: Prehistory Press.

Lukacs, John F., and J. N. PaL

1993 Mesolithic existence in north India. Current Anthropology 34(5): 745-765.

1996 Chronology and diet in Mesolithic north India: A preliminary report of the AMS C ${ }^{14}$ dates, ${ }^{15} \mathrm{C}$ isotope and their significance, in Colloquia of the XIII international congress of Prehistoric Sciences and Protohistoric Sciences: 16(23):301-311, ed. G. E. Afanas'ev, S. Cleuziou, and J. R. Lukacs. Forli: ABACO edizioni.

2003 Skeletal Variation among Mesolithic People of the Ganga Plains: New Evaluation of Habitual Activity and Adaptation to Climate. Asian Perspectives 42(2):329-351.

Macaulay, Vincent, Catherine Hill, Alessandro Achilli, Chiara Rengo, Douglas Clarke, William Meehan, James Blackburn, Ornella Semino, Rosaria Scozzari, Fulvio Cruciani, Adi Taha, Norazila Kassim Shaari, Joseph Maripa Raja, Patimah Ismail, Zafarina Zainuddin, William Goodwin, David Bulbeck, Hans-Jürgen Bandelt, Stephen Oppenheimer, AntoNiO TORRONi, AND Martin Richards

2005 Single, rapid coastal settlement of Asia revealed by analysis of complete mitochondrial genome. Science 308:1034-1036.

Mahadevan, Iravatham

1977 The Indus Script: Texts, Concordance and Tables. New Delhi: Archaeological Survey of India.

Mallory J, and D. Q. Adams

2006 The Oxford Introduction to Proto-Indo-Europeans and the Proto-Indo-European World. New York: Oxford University Press.

McElreavey, K., and Lluis Quintana Murci

2005 A population genetics perspective of the Indus Valley through uniparentally-inherited markers. Ann. Hum. Biol. 32(2): 154-162.

Meadow, Richard H.

1987 Faunal exploitation patterns in eastern Iran and Baluchistan: A review of recent investigations, in Orientalia Iosephi Tucci Memoriae Dicata: 881-916, ed. G. Gnoli and L. Lanciotti. Rome: Istituto Italiano per il Medio ed Estremo Oriente.

1993 Animal domestication in the Middle East: A revised view from the Eastern Margin, in Harappan Civilisation: 295-320, ed. G. L. Possehl. New Delhi: Oxford and IBH Publishing Co. Pvt. Ltd.

Meadow, Richard H., and Ajita K. Patel

2003 Prehistoric pastoralism in northwestern South Asia from the Neolithic through the Harappan Period, in Indus Ethnobiology: New Perspectives from the Field: 65-93, ed. S. Weber and W. Belcher. Lanham, MD: Lexington Books (Rowman and Littlefield Publishing Group). 
Metspalu, Mait, Toomas Kivisild, Ene Metspalu, Jüri Parik, Georgi Hudjashov, Katrin Kaldma, Piia Serk, Monika Karmin, Doron M. Behar, M. Thomas, P. Gilbert, Phillip Endicott, Sarabjit Mastana, Surinder S. Papiha, Karl Skorecki, Antonio Torroni, and Richard Villems

2004 Most of the extant mtDNA boundaries in South and Southwest Asia were likely shaped during the initial settlement of Eurasia by anatomically modern humans. BMC Genetics $5: 26$.

Misra, V. N.

1973 Bagor-a late Mesolithic settlement in North-West India. World Archaeology 5(1): 92-110.

1985 The Acheulian succession at Bhimbetka, Central India, in Recent Advances in Indo-Pacific History: 35-47, ed. V. N. Misra and Peter Bellwood. Leyden: E. J. Brill.

1996 History and context of Mesolithic research at Allahabad University, Allahabad, India, in Colloquia of the XIII International Congress of Prehistoric Sciences and Protohistoric Sciences: 245-248, ed. G. E. Afanas'ev, S. Cleuziou, and J. R. Lukacs. Forli: ABACO edizioni.

2001 Human colonization of India. J. Biosci 26 (4 suppl.): 491-531.

2002 Mesolithic Age in India, in Indian Archaeology in Retrospect: Prehistory-Archaeology of South Asia: 111-126, ed. S. Settar and R. Korisettar. New Delhi: Manohar.

Obeyesekere, G.

Colonial Histories and Vadda Primitivism. http://vedda.org/obeyesekere1.htm

PAL, J. N.

2002 The Middle Palaeolithic cultures of South Asia, in Indian Archaeology in Retrospect: Prehistory-Archaeology of South Asia: 67-84, ed. S. Settar and R. Korisettar. New Delhi: Manohar.

Palanichamy, Malliya, G. Sun Chang, Suraksha Agrawal, Hans-Jürgen Bandelt, QingPeng Kong, Faisal Khan, Cheng-Ye Wang, Tapas K. Chaudhuri, Venkatramana Palla, and YA-PING ZHANG

2004 Phylogeny of mitochondrial DNA macrohaplogroup N in India, based on complete sequencing: Implications for the peopling of South Asia. American Journal of Human Genetics 75 : 966-978.

Patel, Ajita K.

2008 New radiocarbon determinations from Loteshwar and their implications for understanding Holocene settlement and subsistence in North Gujarat and adjoining areas, in South Asian Archaeology: 123-134, ed. Ellen Raven. Groningen: Egbert Forsten.

Piggott, Stuart

1943 Dating the Hissar Sequence-the Indian evidence. Antiquity 17(68):169-182.

1950 Prehistoric India. Harmondsworth, UK: Penguin Books.

Possehl, Gregory L.

2002 The Indus Civilization: A Contemporary Perspective. Oxford: Alta Mira Press.

Potts, DANiel

1999 The Archaeology of Elam: Formation and Transformation of an Ancient Iranian State. Cambridge: Cambridge University Press.

Quintana Murci, Lluis, Raphaëlle Chaix, R. Spencer Wells, Doron M. Behar, Hamid Sayar, Rosaria Scozzari, Chiara Rengo, Nadia Al-Zaheri, Ornella Semino, A. Silvana Santachira Benerecetti, Alfredo Coppa, Qasim Ayub, Aisha Mohyuddin, Chris TylerSmith, S. Qasim Mehdi, Antonio Torroni, and Ken McElreavey

2004 Where West meets East: The complex mtDNA landscape of the Southwest and central Asian Corridor. American Journal of Human Genetics $74: 827-845$.

Quintana Murci, Lluis, C. Krausz, T. Zerjal, S. Hamid, M. Hammer, S. Q. Mehdi, Q. Ayub, R. Qamar, A. Mohyuddin, U. Radhakrishna, M. Jobling, C. Tyler-Smith, and K. McELREAVEY

2001 Chromosome lineages trace diffusion of people and languages in Southwestern Asia. American Journal of Human Genetics 68: 537-542.

Raju, D. R., and P. C. Venkatasubbaiah

2002 The archaeology of the South Asian Lower Paleolithic: History and current status, in Indian Archaeology in Retrospect: Prehistory-Archaeology of South Asia: 85-110, ed. S. Settar and R. Korisettar. New Delhi: Manohar. 
Rendell, Helen R., Robin W. Dennell, and M. Halim

1989 Pleistocene and Paleolithic investigations in the Soan Valley, Northern Pakistan. British Archaeological Reports International Series 544.

RenFrew, COLIN

1987 Archaeology and Language: The Puzzle of Indo-European Origins. Cambridge: Cambridge Press.

Richards, Martin, Vincent Macaulay, Vega E. Hickey, Brian Sykes, V. Guida, Chiarra Rengo, D. Sellitto, F. Cruciani, Toomas Kivisild, Richard Villems, M. Thomas, S. Rychkov, O. Rychkov, Y. Rychkov, M. Gölge, D. Dimitrov, E. Hill, D. Bradley, V. Romano, F. Calì, G. Vona, A. Demaine, S. Papiha, C. Triantaphyllidis, G. Stefanescu, J. Hatina, M. Belledi, A. Di Rienzo, A. Novelletto, A. Oppenheim, S. Nørby, S. Santachiara-Benerecetti, R. Scozzari, A. Torroni, and H. J. Bandelt

2000 Tracing European founder lineages in Near Eastern mtDNA pool. American Journal of Human Genetics 67:1251-1276.

Richards, Martin, Vincent Macaulay, Antonio Torroni, and Hans-Jürgen Bandelt

2002 In search of geographical patterns in European mitochondrial DNA. American Journal of Human Genetics $71: 1168-1174$.

Richards, Martin, Chiara Rengo, Fulvio Cruciani, Fiona Gratrix, James F. Wilson, Rosaria Scozzari, Vincent Macaulay, and Antonio Torroni

2003 Extensive female-mediated gene flow from Sub-Saharan Africa into Near Eastern Arab populations. American Journal of Human Genetics 72 : 1058-1064.

Robins G.

in press Dental histology and paleodemography, in Human Skeletal Remains from Damdama: An Indian Mesolithic Site: ed. J. R. Lukacs, R. Pastor, G. Robbins, and G. Nelson. John and Erica Hedges Ltd., U.K.: BAR International Series.

SALI, S. A.

1985 The Upper Palaeolithic culture at Patne, District Jalgaon, Maharashtra, in Recent Advances in Indo-Pacific History: 137-145, ed. V. N. Misra and Peter Bellwood. Leyden: E. J. Brill.

Samzun, Anaïck, and Pascal Sellier

1985 First anthropological and cultural evidence for the funerary practices of the Chalcolithic population of Mehrgarh, Pakistan. South Asian Archaeology 1989: 91-119, ed. J. Shotsman and M. Taddei. Naples: Instituto Universitario Orinetale.

Sellier, Pascal

1992 The contribution of Paleoanthropology to the interpretation of a functional funerary structure: The graves from Neolithic Mehrgarh Period IB, in South Asian Archaeology: 253-266, ed. Catherine Jarrige. Madison, WI: Prehistory Press.

Shaffer, J. G., And D. A. Licthenstein

2005 South Asian archaeology and the myth of Indo-Aryan invasions, in The Indo-Aryan Controversy: Evidence and Inference in Indian History: 75-104, ed. Edwin F. Bryant and Laurie L. Patton, New York: Routledge.

Sharma, G. R.

1970 Image of bone figurine from Belan Valley in Uttara Pradesh, north India (Pl L1 XB). New Delhi: Archaeological Survey of India.

Stein, A.

1929 An Archaeological Tour in Waziristan and Northern Baluchistan, Memoirs of Archaeological Survey of India 37. New Delhi: Archaeological Survey of India.

1931 An Archaeological Tour to Gedrosia. New Delhi: Cosmo Publications.

STRINGER, Chris

2000 Coasting out of Africa. Nature 405:24-27.

2002 Modern human origins: Progress and prospects. Phil. Trans. R. Soc. Lond. B. 357:563579.

Thangaraj, Kumarasamy, Gyaneshwer Chaubey, Toomas Kivisild, Alla G. Reddy, Vijay

Kumar Singh, Avinash A. Rasalkar, and Lalji Singh

2005 Reconstruction of the origin of Andaman Islanders. Science 308:996. 
Thomas, P. K., P. P. Joglekar, V. D. Mishra, J. N. Pandey, and J. N. Pal

1996 Faunal evidence for the Mesolithic food economy of the Gangetic Plain with special reference to Damdama, in Colloquia of the XIII International Congress of Prehistoric Sciences and Protohistoric Sciences: 16(23) :255-266, ed. G. E. Afanas'ev, S. Cleuziou, and J. R. Lukacs. Forli: ABACO edizioni.

WaKankar, Vishnu, ANd Robert R. Brooks

1976 Stone Age Painting in India. Bombay: Taraporevala and Sons.

WheEler, Mortimer

1968 The Indus Civilization: Supplementary Volume to The Cambridge History of India. Cambridge: Cambridge University Press.

\begin{abstract}
The evolution of humans from primates is well attested in Africa, considered to be the only place where the ancestors of modern humans could have evolved. The most ancestral human form, Homo erectus, is also thought to have migrated out of Africa. Recent genetic research has added support to an "Out of Africa" migration of modern man. However, the latest findings of population genetics have, by challenging the route of exodus, placed Asia and especially South Asia in a particularly prominent position. This new idea that humans emerging out of Africa undertook a long journey along the coasts of Asia toward Australia has also received recent support from archaeology. The long-standing belief that modern humans reached Europe by first journeying through the Levant, was based on the discovery of modern looking skeletons in southern France. This discovery of the "Cro-Magnons" in France spurred an intense search for more evidence of human presence in Europe. The wealth of data thus accumulated in Africa and Europe has formed the basis for all the discussion on human evolution and migration. Asia by contrast has suffered neglect both in terms of lack of interest and exploration of the same magnitude accorded Africa and Europe. What evidence exists has only attracted passing notice, the bulk of the data eluding the attention of western scholars. This article attempts to address this imbalance by bringing together all current information relating to the fields of anthropology, archaeology, and genetics. The area covered is by size enormous, but the focus is on the strength of evidence for colonization of South Asia from outside as opposed to contributions made by the indigenous people. KeYwORDs: South Asia, Homo sapiens, mtDNA, symbolic behavior.
\end{abstract}

